\title{
Programa Monumenta: uma experiência em preservação urbana no Brasil
}

Romeu Duarte Junior*

\section{Resumo}

Com este artigo, objetiva-se conhecer e analisar um programa oficial de preservação urbana (Programa Monumenta) desenvolvido pelo Governo Federal e seus parceiros públicos e privados, bem como avaliar seus resultados. O trabalho foi desenvolvido segundo um fluxo cronológico e produzido mediante a realização de pesquisa bibliográfica e documental. É também uma revisão da literatura sobre o assunto, destacando-se a análise de trabalhos produzidos pelo Instituto do Patrimônio Histórico e Artístico Nacional - IPHAN e de artigos elaborados por especialistas em publicações diversas. Espera-se que o estudo em tela, conquanto simples e sem maiores pretensões além das anunciadas, possa contribuir para a discussão das questões relacionadas ao complexo problema da preservação dos sítios históricos urbanos em nosso país.

Palavras-chave: Planejamento territorial urbano. Proteção do patrimônio cultural. Programa Monumenta.

\section{Programa Monumenta: a experience in urban preservation in Brazil}

\begin{abstract}
This article deals with the concepts and goals of the Programa Monumenta, an official urban preservation program led by the brazillian government and BID from 2001 to the present day, focusing on the complex problem of cultural heritage in the historic sites of Brazil.
\end{abstract}

Key-words: Urban preservation planning. Protection of cultural property. Programa Monumenta. 


\section{Introdução}

É impossível estabelecer uma reflexão sobre o Programa Monumenta, plano de preservação urbana criado em conjunto pelo Governo Federal e o Banco Interamericano de Desenvolvimento - BID, sem que se faça uma análise sobre os esforços anteriormente desenvolvidos e em progresso para salvaguardar as cidades históricas no Brasil, com referência aos trabalhos de mesma natureza desenvolvidos em escala mundial e na difícil relação entre preservação e desenvolvimento sócioeconômico.

A literatura sobre o tema nos ensina que, no alvorecer do urbanismo (final do século 19), a preservação da cidade antiga tornou-se imperiosa quando colocou-se como um obstáculo ao livre curso deste novo campo teórico e prático, então completamente voltado ao desenvolvimento avassalador da cidade industrial. Logo após, a destruição provocada pelos dois conflitos mundiais nas cidades europeias e a posição hegemônica dos Estados Unidos na cena capitalista mundial engendraram, respectivamente, dois modelos de enfrentamento do problema. No primeiro caso, a recuperação das cidades e sítios de interesse cultural, amparada em novas destinações, alia-se ao planejamento urbano, considerando os valores histórico-artístico e de uso da cidade-monumento e do seu contexto, com procedimentos claros de conservação e restauro, de que é exemplo a notável intervenção realizada em Bolonha, Itália, no início dos anos de 1970. CHOAY evoca o papel central de Gustavo Giovannoni nessa formulação, dizendo que sua contribuição teórica

antecipa, de forma simultaneamente mais simples e mais complexa, as diversas políticas das "áreas protegidas" que foram desenvolvidas e aplicadas na Europa a partir de 1960. Contém, igualmente, em germe, seus paradoxos e dificuldades. (CHOAY, 2001, p. 203).

No segundo, no rastro da devastação impiedosa e criativa do tecido antigo em prol de uma nova ordem urbanística, protagonizada, dentre outros, por figuras como o engenheiro norte-americano Robert Moses, será criada uma expressão-chave, transformada posteriormente numa autêntica "palavra-valise": renovação urbana. Em nosso país, sob diversas acepções e pretextos, este termo, opção preferida como forma de intervenção nas cidades, serviu de justificativa a ações destrutivas das 
áreas urbanas de valor cultural agregado, seja nas capitais ou em pequenas aglomerações do interior, num tempo em que progresso e memória não combinavam.

Será a Carta de Quito (OEA, 1964) o documento que, pioneira e corajosamente, irá apontar, a partir do campo latino-americano, as possibilidades da preservação do patrimônio cultural operar como pressuposto do desenvolvimento sócio-econômico mediante a adoção de um plano sistemático de revalorização do acervo em função do desenvolvimento econômico-social. (CURY, 2001).

Denunciando a mutilação e a degradação do perfil de muitas cidades iberoamericanas "em nome de um mal entendido e pior administrado progresso urbano", este causado por um "processo anárquico de modernização", a carta afirmou que os monumentos arqueológicos, históricos e artísticos, e, portanto, as cidades históricas, constituíam também "recursos econômicos", defendendo a mobilização dos "esforços nacionais no sentido de procurar o melhor aproveitamento dos recursos monumentais de que se dispunha, como meio indireto de favorecer o desenvolvimento econômico do país". Numa palavra: o documento propõe que o fortalecimento dos agentes e das medidas preservacionistas se dê com vistas a que o patrimônio cultural fosse revalorizado em função do interesse público e para benefício econômico dos países, cidades e comunidades. As demais cartas que lhe sucederam só reforçaram essa vertente de pensamento.

No caso brasileiro, mesmo com a ação devotada do órgão federal de preservação, o Instituto do Patrimônio Histórico e Artístico Nacional - IPHAN, neste período as cidades e sítios históricos sofriam com a completa desvinculação entre a preservação, o planejamento urbano e as alternativas de desenvolvimento sócioeconômico, num quadro muito semelhante ao desenhado pela Carta de Quito. Os Compromissos de Brasília (1970) e Salvador (1971), conquanto inspirados nos termos deste documento e da Carta de Nairobi, ensaiaram timidamente uma saída para o impasse através da atividade turística. Faltava, entretanto, um programa de cunho governamental que definisse parcerias entre os agentes públicos e privados, tratasse a preservação urbana como uma faceta do planejamento urbano e um instrumento de superação sócio-econômica do subdesenvolvimento e conceituasse 
o patrimônio cultural como um recurso ativo, num tempo em que as cidades históricas do país deixavam de ser vistas como monumentos acabados e passavam a ser tratadas como documentos.

Neste passo, objetiva-se, com o presente artigo, descrever e discutir a formação e a evolução conceitual do Programa Monumenta/BID, bem como suas realizações ao longo dos últimos quinze anos, considerando experiências e contribuições anteriores, tais como o Programa de Reconstrução das Cidades Históricas - $\mathrm{PCH}$, e o rebatimento, em seu desenvolvimento, das diretrizes políticas que animaram os governos de Fernando Henrique Cardoso e de Luís Inácio Lula da Silva. Na mesma linha, buscar-se-á produzir uma reflexão sobre a mudança de consideração relativa às cidades e aos sítios históricos no Brasil, os quais, nos últimos setenta anos, foram vistos como monumentos, documentos, empreendimentos e instrumentos.

\section{Preservação do patrimônio urbano no Brasil: antecedentes}

O Brasil foi um dos primeiros países do mundo a demonstrar preocupação e a desenvolver medidas práticas com relação à preservação do patrimônio edificado urbano. Em 1933, quatro anos antes da criação do IPHAN pelo Presidente Getúlio Vargas, a cidade de Ouro Preto foi tombada como "monumento nacional" (Decreto Presidencial $N^{\circ}$ 22.928). Em 1938, já sob a égide da instituição e amparado legalmente pelo Decreto $N^{\circ} 25 / 37$, mais seis cidades mineiras (Diamantina, Mariana, Sabará, São João Del Rei, Serro e Tiradentes) são tombadas no âmbito federal.

Segundo a ótica da atual administração do IPHAN, essas ações, lideradas por um grupo de intelectuais modernistas, "inauguram uma prática de defesa e conservação de sítios históricos inovadora para a época e deixou como legado mais de uma centena de conjuntos arquitetônicos e urbanísticos protegidos em todo o país" (PAC..., 2009, p. 5)

Vale dizer que o conceito de cidade e/ou sítio histórico empregado pelos técnicos do patrimônio de então para o tombamento de áreas urbanas era o de "cidademonumento": obras de arte acabadas e sublimes, valorizadas por expressarem as manifestações da arquitetura e do urbanismo barroco, levantadas com o risco português, pelo braço escravo e com os materiais da terra. Até o início dos anos de 
1970 ainda era esse o pensamento que norteava a ação do IPHAN, voltada muito mais à valorização da "pedra-e-cal" do que à compreensão do complexo amálgama de história, sociedade e estética que constitui as nossas cidades.

Por essa época, reflexo do alargamento do campo patrimonial, das dimensões tipológica e cronológica das expressões patrimoniais e do próprio público do patrimônio, produz-se uma nova forma conceitual para se pensar o patrimônio urbano: a "cidade-documento". Nesta formulação, os processos sócio-históricos de formação e evolução das cidades são tão ou mais importantes do que as expressões estéticas, constituindo-se a preservação como uma notável função urbana, no mesmo patamar da habitação, do trabalho, da recreação e da circulação, e a fruição do patrimônio como algo decorrente do direito à cidade.

Em nosso país, a questão da preservação do patrimônio urbano é tarefa de desenvolvimento recente. Segundo Zanchetti,

\begin{abstract}
surge em meados da década de 1970 e pode ser considerado resultado do esforço de atualização empreendido pelo então Serviço de Patrimônio Histórico e Artístico Nacional (SPHAN) em finais da década de 1960. À época, este órgão de proteção buscava se instrumentalizar de forma a definir uma política capaz de fazer frente à problemática de sítios históricos que começavam a ser alvo do avanço urbano industrial. (ZANCHETTI et al, 1995, p. 1).
\end{abstract}

Contemporâneo dessa visão do problema, é instituído pelo Governo Federal, em 1973, o Programa de Reconstrução das Cidades Históricas - PCH. Desenvolvido prioritariamente em algumas capitais e cidades nordestinas, foi incorporado ao IPHAN no final de 1979. As ideias que deram lugar ao $\mathrm{PCH}$ muito deveram à atitude do Dr. Rodrigo Mello Franco de Andrade, que, preocupado com o poder deletério do crescimento urbano e do desenvolvimento econômico, solicitou apoio técnico da Unesco para a proteção das cidades históricas brasileiras. A Unesco, por sua vez, enviou ao país o Arq. Michel Parent, inspetor dos monumentos históricos franceses, cuja missão em terras brasileiras, conforme aponta Halévy (1998, p. 20), "inaugurou uma nova abordagem da preservação das cidades históricas, com uma importância grande dada ao turismo como fator de revitalização". 


\section{Assim se refere Fonseca ao $\mathrm{PCH}$ :}

[...] tinha como objetivo criar infra-estrutura adequada ao desenvolvimento e suporte de atividades turísticas e ao uso de bens culturais como fonte de renda para regiões carentes do Nordeste....A criação do $\mathrm{PCH}$ veio suprir basicamente a falta de recursos financeiros e administrativos do IPHAN, continuando a cargo desta instituição a referência conceitual e técnica. Propiciou, por outro lado, a criação, durante as décadas de 70 e 80 , de órgãos locais de patrimônio e a elaboração de legislações estaduais de proteção, abrindo os caminhos efetivos para a descentralização. (FONSECA, 1997, p. 161)

Diversos fatores contribuíram para a extinção do PCH (1983), principalmente a falta de sustentabilidade econômico-financeira dos projetos escolhidos, vez que "dentre os 22 projetos concluídos até 1976, apenas seis eram capazes de gerar os recursos para a sua própria conservação" (SANT'ANNA, apud HALÉVY, 1998, p. 21), bem como a ausência de uma análise apurada do sítio histórico urbano: em muitos casos, a direção do programa teria feito uso de

critérios políticos de distribuição de recursos e os planos diretores que promoveu de nada serviram para a preservação das cidades. Passaram do arquitetônico fachadista para o urbanismo macro, abstrato e tecnocrático [...] sem se ater às formas que caracterizam a cidade. (MOTTA, apud HALÉVY,1998, p. 21).

De outra parte, clamava-se por uma mais generosa e inclusiva consideração do patrimônio cultural brasileiro, ao mesmo tempo em que se exigia a criação de uma estrutura operativa mais eficiente para dar conta das tarefas preservacionistas oficiais. Nas palavras de Fonseca,

para setores modernos e nacionalistas do governo, era necessário não só modernizar a administração dos bens tombados, como também atualizar a própria composição do patrimônio, considerada limitada a uma vertente formadora da nacionalidade, a lusobrasileira, a determinados períodos históricos, e elitista na seleção e no trato dos bens culturais, praticamente excluindo as manifestações culturais mais recentes, a partir da segunda metade do século XIX, e também a cultura popular. (FONSECA, 1997, p. 152).

Mesmo com todos os problemas de origem e um histórico de poucas realizações, marcado ainda pelo clientelismo e o dirigismo político, $\mathrm{o} \mathrm{PCH}$ teve como méritos 
expor o complexo problema da preservação urbana num momento em que o país conhecia taxas de crescimento elevadas, cujo rebatimento nas cidades era a "metropolização descapitalizada" (Jorge Hardoy) com seus arrasadores símbolos de progresso e desenvolvimento. Nos últimos anos, o $\mathrm{PCH}$ vem tendo suas ideias reabilitadas a partir de análises realizadas em diversos fóruns e seminários, tais como o recentemente desenvolvido pelo IPHAN em Ouro Preto (dezembro de 2009) denominado "Patrimônio, Desenvolvimento e Cidadania" para apresentação do Programa de Aceleração do Crescimento - Cidades Históricas. De acordo com a atual administração da instituição,

[...] ao longo destes mais de 70 anos, o IPHAN realizou, articulou e promoveu inúmeras ações...Entre elas, cabe destacar o Programa de Cidades Históricas...Desenvolvido entre 1973 e 1983, buscava integrar a riqueza patrimonial às políticas de desenvolvimento econômico e regional, com ênfase no turismo. A profunda crise financeira que se abateu sobre o país na década de 1980, impediu a continuidade do programa, que só foi retomado em 1999 com a implantação do Programa Monumenta. (PAC..., 2009, p. 5).

\section{A criação do Programa Monumenta-BID: a preservação como função urbana, o patrimônio como recurso}

\subsection{Programa Monumenta-BID: conceituação e programa de trabalho}

Em 1995, o Ministério da Cultura - MinC e a direção do Banco Interamericano de Desenvolvimento - BID deram início aos entendimentos para viabilizar um programa de preservação do patrimônio cultural do país, com ênfase nos sítios e conjuntos urbanos. No ano seguinte, o IPHAN elabora a Carta-Consulta ao BID, aprovada em agosto. Na sequência, são discutidos os fundamentos do programa e fixados os locais de intervenção prioritária, a saber, Olinda, Recife, Salvador, Ouro Preto, Rio de Janeiro e São Paulo. Nesse mesmo período é também criada uma comissão técnica no IPHAN para apoio à equipe do Monumenta e são contratados os primeiros consultores, em cooperação com a Unesco.

Em 1997, cria-se a Unidade Central de Gerenciamento - UCG no MinC e se redefine a participação do IPHAN no programa. O Acordo de Cooperação Técnica para a execução do Monumenta entre o MinC e a Unesco é firmado em 1998. No ano seguinte, é criado o Grupo de Trabalho - GT/IPHAN para efetuar a coordenação 
das ações do órgão no âmbito do programa. Neste mesmo ano, a Missão de Negociação reúne técnicos brasileiros para a formatação definitiva do contrato de empréstimo com o BID, em Washington. Em 1999, em Petrópolis-RJ, é assinado o contrato de empréstimo com o governo brasileiro. Em 2000, o programa inicia-se efetivamente.

Financiado pelo BID e apoiado tecnicamente pela Unesco, o Programa Monumenta foi instituído pelo MinC, no governo do Presidente Fernando Henrique Cardoso (1995-2002). Em tempos de acalorado debate sobre temas como mundialização e neoliberalismo político-econômico, não poderia ser outro o conceito que animou a criação do programa:

[...] se desejarmos construir um país capaz de extrair da globalização suas maiores recompensas, devemos democratizar a imagem do nosso patrimônio cultural, fazê-lo aberto e plural e próximo à realidade da nossa estrutura e das raízes nacionais e ao perfil desenvolvimentista de nossa economia. (WEFFORT, 2001, p. 40).

Nessa formulação, o modelo preservacionista brasileiro (o próprio patrimônio e o órgão federal responsável por sua preservação) era considerado um legado anacrônico do governo varguista e, como tal, carecia de profunda atualização face ao novo quadro político e econômico nacional e internacional. Segundo as palavras de um dos ideólogos de primeira hora do programa,

até recentemente, a política oficial de preservação,...contribuiu para distanciar o patrimônio do povo, que pôde apenas, de forma muito tênue, identificar-se com os problemas da oligarquia rural: a cultura dos brancos, portugueses e católicos...de outra parte, a legislação patrimonial gerada durante o período varguista caracterizou-se pela centralização e pelo paternalismo. Ao governo federal foi reservada a responsabilidade final pela conservação do acervo histórico. (TADDEI NETO, 2001, p. 43-44).

Para os seus autores, além dos entraves apontados acima, as ações do governo federal no tocante à preservação urbana fracassaram por uma série de outros motivos: os recursos limitados dos proprietários de imóveis antigos, habitantes de cidades pobres e desassistidas; a redução da rotina de manutenção desses imóveis; a decorrente deterioração do parque imobiliário histórico; a requisição de custosos 
serviços de restauro e conservação, onerando os cofres públicos e aumentando a carga orçamentária; e a limitação da elaboração de inventários e a diminuição do número de bens protegidos, face às restrições no orçamento experimentadas pelo governo federal desde a década de 1970. Para Taddei Neto (2001, p. 45), com a adoção de novas políticas culturais na década de 1990, o panorama do patrimônio cultural brasileiro estaria mudando: "o ponto de inflexão ocorreu quando os parceiros do setor privado envolveram-se nesse domínio, atraídos por uma lei federal que recompensa programas de incentivo baseados em taxas". Segundo o mesmo autor,

esse novo mecanismo diminuirá a pressão sobre os recursos do governo federal. Ele permitirá ao governo organizar suas fontes de financiamento de forma mais flexível, tanto para extensão do marco regulatório e legal relacionado à proteção da propriedade cultural quanto pela ampliação do número de bens tombados sob sua responsabilidade.

$[\ldots]$

os aluguéis provenientes dos edifícios restaurados com fundos do programa são coletados para compor um fundo municipal, específico para financiar trabalhos de restauração. Esses recursos serão reaplicados em novas áreas agendadas para restauração. (TADDEI NETO, 2001, p. 45).

Essas afirmações geram questionamentos: Como fazer a iniciativa privada de cidades pobres, como a maioria das históricas, colocadas à margem do desenvolvimento, investir em sua recuperação? Como transferir à iniciativa privada uma atribuição que é própria e intransferível do governo federal, qual seja, a de organizar a proteção do patrimônio histórico e artístico nacional? Diminuir a pressão sobre os recursos do governo federal e distender o marco regulatório e legal ligado à proteção do patrimônio cultural foram meras figuras retóricas ou, na verdade, significaram, quando proferidas, a redução do orçamento governamental relacionado à preservação do patrimônio cultural e a abolição do Decreto 25/37 e do próprio IPHAN?

Arthur Darling, economista do BID, traça as diretrizes de ação do Programa Monumenta em seu início, a partir de algumas constatações pessoais: a maior parte do patrimônio construído brasileiro encontra-se em áreas urbanas e em mãos de proprietários privados; o gerenciamento do acervo tombado é devido ao IPHAN; as intervenções nos bens tombados são antes analisadas e aprovadas pelo órgão 
federal, registrando-se o emperramento do processo pela grande quantidade de entraves burocráticos; inexistência de normas de preservação; pareceres arbitrários e morosos, gerando intervenções irregulares e danosas aos monumentos. As premissas do programa são consubstanciadas no seguinte objetivo:

\begin{abstract}
desenvolver uma estratégia de conservação sustentável dirigida aos bens imóveis tombados pelo IPHAN através do estabelecimento de prioridades, do incentivo ao fortalecimento institucional das municipalidades e do estímulo ao setor privado para a preservação do patrimônio, mediante a conscientização do público quanto à sua importância e manutenção. (DARLING, 2001, p. 195).
\end{abstract}

E quanto à priorização do atendimento dos sítios históricos pelo Monumenta? Conforme o autor, inicialmente dever-se-ia levantar e avaliar os principais problemas que contribuem para a perda do patrimônio edificado protegido no âmbito federal. Com base nesse cenário, seria realizada a seleção dos sítios históricos tidos como prioritários para abordagem por parte do programa, considerando-se ainda a relevância histórico-arquitetônica de cada um, a maior ou menor capacidade de atração de apoios e parceiros e a maior suscetibilidade a usos econômicos, culturais e sociais.

Especificamente com relação aos municípios, caberia a estes desenvolver

projetos de preservação integrada, os quais são...revitalizadores da economia local de forma a que se constituam como âncoras de sustentabilidade para os sítios históricos. Isso dá a oportunidade ao município do mesmo se considerar "dono" do projeto. Os projetos de preservação integrada incluem a restauração do patrimônio tombado, reparo e ampliação da infra-estrutura urbana, criação de acessos viários, melhorias no espaço público..., criação de estacionamentos, iluminação pública e segurança. (DARLING, 2001, p. 196)

Forçoso dizer que, no seu começo, o Programa Monumenta foi conceituado como instância autônoma e externa ao IPHAN, atuando crítica e propositivamente quanto à atuação deste órgão, e aliada a outros parceiros para a consecução dos seus objetivos. Nesse escopo, ao instituto caberia apenas a resolução dos problemas técnicos da preservação e o duro cotidiano da fiscalização, com sua ação restringida aos parcos recursos disponibilizados pelo MinC. 
Para a operação do programa, seria necessário constituir um fundo de preservação, mantido em uma instituição financeira por um período de 20 anos, prazo correspondente à duração do empréstimo concedido pelo BID. A alimentação do fundo seria efetuada por várias fontes: contrapartidas municipais relativas à valorização da propriedade predial e ao aumento da atividade comercial e de serviços, ambas ligadas à revitalização das áreas focadas pelo projeto e ao sucesso destes processos, bem como reembolsos viabilizados pelo programa ao setor privado, contribuições de usufruto e taxas de concessão derivadas da restauração de áreas e imóveis públicos utilizados por particulares. A definição da área para desenvolvimento do programa era considerada como central para o emprego do dinheiro do fundo e o êxito do empreendimento:

a utilização de recursos do fundo de preservação ocorrerá somente na conservação de monumentos públicos tombados, prioritariamente aqueles inseridos na área definida para implementação do programa, geralmente um setor do sítio histórico...Como terceira prioridade, o programa abrange também imóveis tombados nos âmbitos municipal e estadual, desde que estejam incluídos nas áreas do projeto. Se sobrarem recursos, deverão ser empregados com a mesma finalidade na área de influência vizinha à área do projeto. (DARLING, 2001, p. 198).

Ao setor privado é conferida uma missão especial:

a chave para a sustentabilidade de áreas urbanas de valor histórico-cultural é estimular a atividade econômica de forma a que as pessoas tenham interesse econômico em preservar a área. Nesse processo, a participação do setor privado é crítica. (DARLING, 2001, p. 199).

Para estimular a participação deste segmento produtivo entendeu-se necessário definir precisa e rigorosamente os usos permitidos e as adaptações passíveis de serem suportadas pelos imóveis protegidos. Essa consideração segue acompanhada de uma estocada no órgão federal de patrimônio, em mais uma desqualificação do seu trabalho:

no Brasil, não existem tais regras nem tampouco diretrizes para manter tipos diferentes de edifícios históricos e conservar suas características. Em vez disso, os técnicos do patrimônio - os quais enxergam o seu papel apenas em termos de proteção, numa 
abordagem conservadora do patrimônio - consideram cada caso como um caso isolado. $O$ resultado é um lento e imprevisível processo freqüentemente considerado arbitrário, que desencoraja investidores potenciais. (DARLING, 2001, p. 199).

Àquela altura, os problemas com os parceiros de ocasião já eram vislumbrados, entretanto sem a profundidade de análise necessária, o que levou o programa, em sua etapa posterior, a uma revisão completa de estratégia, estrutura técnicoadministrativa e metas. Detectou-se que, no âmbito municipal, não havia uma garantia de manutenção permanente do acervo; os municípios contemplados com o programa apresentavam baixas taxas de arrecadação; haveria a possibilidade da existência de conflitos entre as câmaras e as prefeituras na instituição do fundo de preservação; inexistia a garantia quanto ao cumprimento dos compromissos estabelecidos pelo programa por parte das prefeituras municipais e, na mesma linha, quanto a ações não cobertas pelo fundo e de responsabilidade dos municípios. Não se constatou, entretanto, a falta de preparo técnico-administrativo e o desinteresse das prefeituras quanto ao programa, pontos, dentre outros que, no futuro, pesaram fortemente na reformulação da proposta.

Com relação à participação do setor privado, poder-se-ia argumentar que, no mais das vezes, o patrimônio nas cidades históricas brasileiras foi preservado não pelo altruísmo, benemerência ou abnegação de sua população, mas sim pela pobreza e pela perda de vitalidade econômica, o que não encoraja a realização de intervenções nas edificações tombadas. Portanto, terão os ideólogos do Programa Monumenta burilado o conceito de sítio histórico tendo em mente apenas as áreas tombadas das capitais e de cidades detentoras de forte desenvolvimento econômico?

Contudo, todos esses aportes prepararam uma nova transformação conceitual do sítio histórico no ambiente cultural brasileiro: da cidade-monumento, valorizada pelo olhar rigoroso e seletivo dos pioneiros do patrimônio, passando-se pela cidadedocumento, artefato destacado pelo seu próprio processo de formação e evolução urbana, chegou-se à cidade-instrumento, em que as características das anteriores se somam ao exercício da cidadania e à elevação do padrão da qualidade de vida das populações, sem renunciar ao cotidiano da economia, da gestão e do mercado: 
"O Programa Monumenta está financiando a preparação das normas e diretrizes de ação necessárias e tentando incorporar a noção de que o patrimônio é um recurso econômico" (DARLING, 2001, p. 199). Na mesma direção apontam as palavras de Arantes (apud MORI, 2006, p. 57):

\footnotetext{
pensar o patrimônio enquanto recurso não é necessariamente vinculá-lo ao mundo da especulação e dos grandes negócios. É certo que mega-empreendimentos imobiliários urbanísticos e turísticos valem-se dessa tendência e a estimulam; mas é também verdade que programas de geração de renda, de consolidação da cultura pública e de valorização da cidadania nutrem-se e buscam eficácia no fortalecimento do que a população pode fazer, com os recursos de que dispõe e que tradicionalmente acumulou, nos lugares onde vive e em seu próprio modo de vida... Nesse sentido, o patrimônio urbano mostra-se bom para o desenvolvimento sustentável e para a civilidade.
}

A carteira de investimentos para a realização do programa previa, em seu início, a elaboração de diretrizes para orientar a utilização dos edifícios por parte dos investidores privados; a execução de melhorias urbanas; a oferta de incentivos financeiros aos proprietários de imóveis constantes dos sítios históricos para a efetuação de serviços de restauro e conservação predial associadas a baixas taxas de juros; a determinação da preferência, na adaptação dos imóveis restaurados, a atividades comerciais e turísticas; e o estímulo à instalação nos sítios históricos e à participação na gestão do fundo de instituições de cunho cultural.

Por fim, Darling (2001, p. 201) conclui que os países da América Latina não dão conta, com seus próprios recursos, do pesado fardo da preservação urbana. A solução para o problema, em sua ótica, seria priorizar, em termos de ação, aqueles sítios mais importantes; definir normas mais generosas de uso e adaptação dos imóveis; reduzir a margem de riscos dos parceiros potenciais; estabelecer parcerias firmes com as municipalidades, o setor privado, proprietários, moradores e outros grupos de interesse; e criar linhas de incentivo dirigidas à contratação de propostas, à manutenção dos conjuntos tombados e às atividades privadas.

\subsection{Definição da Lista de Prioridades}

Para dar início aos trabalhos do programa de maneira fundamentada, além da arregimentação de uma equipe técnica, foi também contratada uma comissão de 
especialistas para a elaboração de uma Lista de Prioridades de Conservação. De maneira a que fosse atingido o fortalecimento institucional do MinC, o programa definiu como essencial o estabelecimento de um sistema de priorização de suas atividades. Para tanto, foram fixados os seguintes objetivos:

a) preservar áreas prioritárias do patrimônio histórico e artístico urbano sob proteção federal; b) aumentar a conscientização da população brasileira acerca desse patrimônio; c) aperfeiçoar a gestão desse patrimônio e o estabelecimento de critérios para a implementação de prioridades de conservação. (PROGRAMA MONUMENTA, 2005, p. 6).

Como tal, ficam claras as preocupações do programa com os principais problemas enfrentados pela preservação urbana no Brasil: o desconhecimento ou o pouco caso demonstrado pelas comunidades quanto ao seu patrimônio; a falta de critérios precisos para a realização das intervenções necessárias, destituídos de arbitrariedade e burocracia; e o baixo nível da gestão do acervo edificado, dissociada da gestão urbana como um todo. Entretanto, as soluções são formuladas no âmbito de um programa financeiro de recuperação do patrimônio, sem maior integração com o órgão federal responsável pela preservação deste.

No primeiro ano do programa, o Monumenta elaborou a lista de áreas de projeto prioritárias. O rol de prioridades do programa, mais restrito, foi composta pelos sítios e conjuntos classificados nos 20 primeiros lugares. A seleção das áreas a serem analisadas deu-se a partir da identificação de dois grupos, a saber, os sítios históricos urbanos nacionais - SHUNs, correspondentes aos sítios históricos urbanos tombados no âmbito federal, e os conjuntos urbanos de monumentos nacionais CUMNs, estes tombados isoladamente, situados em área urbana e guardando relação de proximidade entre si. Esta categoria foi definida pela associação das seguintes condições e características:

presença de, no mínimo, 02 (dois) monumentos tombados em nível federal; presença de fatores que contribuam para a configuração do conjunto urbano, tais como: inserção em estrutura urbana de interesse de preservação, a ocorrência de elementos urbanísticos catalisadores ou articuladores, assim como a existência de unidade histórica e morfológica do tecido urbano; e inserção em sítio protegido pelos níveis estadual ou municipal ou onde 
se registre a presença de monumentos protegidos nesses níveis. (PROGRAMA MONUMENTA, 2005, p. 17).

De maneira a construir um banco de dados sobre as áreas objeto do programa e facilitar o processo decisório, foram concebidas fichas de informações básicas para os SHUNs e os CUMNs, cujas organizações, praticamente idênticas, só diferiam nas questões relativas aos tombamentos (1).

É mister conhecer em profundidade os conceitos que não só estruturaram a ação do programa como também foram fundamentais para a seleção das áreas e cidades, bem como à definição do que nelas fazer. Produzidos no bojo de um estudo cuja elaboração foi confiada a uma equipe coordenada pelo Prof. Dr. Hist. Istvan Jancsó (2), docente do Departamento de História da USP, partem da apropriação do termo "História" como uma "ciência que procura as ações realizadas pelos homens" (Heródoto) ou uma "ciência dos homens no tempo" (M. Bloch). Para definir a essência dos sítios históricos urbanos nacionais e os conjuntos urbanos de monumentos nacionais, faz-se emprego do artigo primeiro do Decreto $N^{\circ} 25 / 37$, questionando-se a expressão

\footnotetext{
vinculação a fatos memoráveis da História do Brasil", contida neste: "estes lugares da memória devem ser avaliados no sentido de os valorarmos do ponto de vista de sua representatividade ou de sua vinculação ao processo histórico de formação da nacionalidade...Em outras palavras, qual a narrativa que deve fundamentar tal valoração? O que é a História do Brasil?. (JANCSÓ, 2000, p. 1)
}

Serão utilizadas categorias de pensamento situadas para além dos valores físicos e estéticos das áreas e monumentos, remetendo fortemente ao conceito de cidadedocumento. Nessa linha, o compromisso da equipe de consultores com os ditames da Nova História e a negação do Estado-Nação, ferramentas para a definição e valorização de um novo formato patrimonial e a seleção dos sítios históricos urbanos a serem contemplados, é mais do que claro:

abandonando a perspectiva teleológica da justificação do estado nacional, a moderna historiografia preocupa-se em desviar-se dos anacronismos e acentuar a diversidade e a complexidade das possibilidades inscritas no processo histórico...neste sentido, as 
narrativas se tornam hoje complexas, complementares e divergentes. Articulam-se às problemáticas presentes, assumidas pelos historiadores, propostas pela vontade coletiva de inscrição em uma memória, na busca de uma ancestralidade. Procura-se entender os desajustes cronológicos entre as séries factuais, assim como os diversos ritmos correspondentes às diversas dimensões estruturais da vida social. As dinâmicas peculiares da economia, da cultura, da religião, dos hábitos, correlacionam-se de forma a sugerir recortes temporais também peculiares. (JANCSÓ, 2000, p. 2).

Numa palavra: naquele momento, entendia-se necessário avançar na consideração do patrimônio urbano para além dos marcos até então estabelecidos pelo IPHAN. Lugares e expressões que ainda não haviam sido devidamente incorporados ao chamado patrimônio histórico e artístico nacional, talvez por não terem sido produzidos no período colonial e por refletirem a rica diversidade da cultura nacional, eram agora objeto de análise e valorização. Destacando os múltiplos segmentos sócio-culturais pertencentes à sociedade brasileira, todos lutando pela preservação de suas legítimas manifestações, Jancsó $(2000$, p. 2) define o problema que se apresenta aos consultores, no que tange à justificativa da escolha dos sítios históricos urbanos:

a narrativa da história nacional é ela em si um problema para os historiadores. Outras narrativas, complementares ou antagônicas, compõem um conjunto não discreto, ou interrelacionado, que respondem (ou não mais respondem) a posições e interesses diversificados que se acham presentes em nossa sociedade complexa...no âmbito da vida social local, esferas de preservação de uma memória de grupo lutam diante da maquinaria homogeneizadora da indústria cultural triunfante. No quadro atual, estas narrativas podem se entrecruzar, se chocar ou até mesmo se fortalecer.

De maneira a que se produzisse uma metodologia de avaliação e recorte fundamentada em variáveis ponderáveis e numa perspectiva democrática e plural, abordando adequadamente a complexidade e multidimensionalidade da história e da memória coletiva da sociedade brasileira, a equipe de consultores estabeleceu critérios de representatividade histórica e cultural para a montagem de um ranking com cem sítios históricos previamente escolhidos. As premissas que presidiram esse trabalho foram as seguintes: 
- O entendimento do patrimônio cultural como recurso cultural específico, em termos de sua apropriação e de produção, podendo e devendo gerar renda, abandonandose a visão puramente ligada à propriedade e à imobilização no tempo e no espaço;

- A aceitação de que os múltiplos sentidos do patrimônio são socialmente construídos, constituindo-se este como "produção de memória, modo de conferir inteligibilidade ao presente e identidade aos seus possuidores ou consumidores" (JANCSÓ, 2000, p. 3);

- A constatação de que a preservação do patrimônio, como produção de sentido, é um ato político, correspondendo à construção de uma visão do passado, requerendo, pois, a tomada de posição;

- A valorização da diversidade e da complexidade da realidade social brasileira, evitando-se visões generalizantes ou de grupos, com ênfase na pluralidade;

- A compreensão do patrimônio cultural como uma narrativa sobre o nosso passado, o que nos impõe o esforço de conhecer como foi construída para que possa ser recomposta ou negada.

Todas essas premissas conformam o ideário da cidade-instrumento, do patrimônio cultural como recurso social e econômico a ser utilizado como ferramenta do desenvolvimento, situado além do mero empreendimento turístico/de lazer voltado unicamente a visitantes. Essa visão, portanto, inaugura, no Brasil, um terceiro momento na história da conceituação das áreas urbanas de valor histórico-cultural agregado.

A equipe de consultores operou diretamente sobre uma matriz de narrativa histórica, analisando cada sítio em escalas variadas de importância (local, nacional e internacional) para identificar seu significado e relevância. Os procedimentos empíricos empregados resumiram-se à coleta de informações bibliográficas sobre a moderna gestão patrimonial; o levantamento de dados bibliográficos e documentais sobre os sítios analisados; a elaboração de um banco de dados específico; e o estabelecimento de uma tipologia de sítios. Com respeito a este último tópico, a comissão técnica, comprometida com a revisão dos parâmetros até então predominantes na definição do patrimônio brasileiro, ajustou o seu foco: 
as prioridades serão os sítios de caráter complexo, que dêem uma imagem da diversidade de nosso passado e contemplem seu caráter plural, tendo em vista o estabelecimento de uma hierarquia que observe uma narrativa renovada da história nacional. (JANCSÓ, 2000, p. 4).

Antes de apresentar as considerações teórico-metodológicas que iriam balizar o trabalho, os técnicos realizaram uma análise do histórico da política brasileira de preservação. Partindo do princípio de que "todo patrimônio, embora representante de um passado, tem sua significação atribuída no presente" e, deste modo, "o conceito de patrimônio tem que ser compreendido com referência ao contexto histórico de sua aplicação" (JANCSÓ, 2000, p. 5), cunharam as seguintes afirmações:

- No Brasil, o conceito de patrimônio foi entendido como suporte da memória nacional, estando as ações de sua preservação ligadas ao modelo francês do século XIX (estatal, centralizador, planificado, regulamentado);

- O IPHAN é o responsável pelo desenvolvimento dessas políticas, por uma visão do acervo edificado como documento de identidade da nação brasileira, vinculado a "personagens e fatos memoráveis da história do Brasil" (Decreto № 25/37, 1937, Artigo $1^{\circ}$ ) e pela conformação de uma consciência nacional homogênea e unitária, mesmo reconhecendo-se as diferenças regionais;

- Tem-se a arquitetura colonial do século XVIII, mais especificamente o barroco mineiro, como a expressão primordial da arquitetura brasileira e, bem assim, digna de merecer preservação por espelhar os começos do processo de ocupação e organização do território nacional.

Com base em uma visão normativa, o acervo foi tomado como elemento representativo de determinadas características e dos segmentos sociais preponderantes: "a sociedade jamais apareceu como agente desse passado, mas só segmentos seus...e por meio não da norma cotidiana, mas do excepcional, não do coletivo, mas do isolado, do único" (JANCSÓ, 2000, p. 5). Portanto, para os consultores assim se explicava:

- A concentração exagerada do acervo nos estados da Bahia, Maranhão, Minas Gerais, Pernambuco e Rio de Janeiro; 
- A restauração das edificações notáveis concebida através da valorização dos seus elementos originais, desprezando-se os acréscimos adicionados àquelas através dos séculos;

- A desvalorização de manifestações arquitetônicas situadas fora do acervo correspondente ao patrimônio cultural brasileiro na forma como este é conceituado pelo Decreto $N^{\circ} 25 / 37$.

Pugnando pelo abandono de uma visão do patrimônio cultural brasileiro como o acervo das manifestações históricas e artísticas das elites nacionais e defendendo uma abordagem mais antropológica do patrimônio, a comissão técnica afirmou não pretender "desqualificar o IPHAN e seus precursores, mas apenas situá-los num determinado momento histórico de montagem do Estado brasileiro, que não mais se coaduna com a realidade atual que pede um estado democrático e pluralista" (JANCSÓ, 2000, p. 6). Idiossincrasias à parte, em especial aquelas relacionadas a um "rigoroso" exame dos resultados de uma instituição sempre às voltas com parcos recursos humanos e financeiros e, mesmo assim, responsável direta pela preservação de uma grande quantidade de bens culturais materiais e imateriais de valor inestimável, em verdade o IPHAN já desenvolvia, à época, uma linha de trabalho que tinha como eixo uma ampliada conceituação do patrimônio cultural brasileiro. Não somente relacionada à valorização das expressões de grupos sociais ainda não contempladas como "patrimônio nacional", como também ao crescimento do público interessado nas questões patrimoniais e à aproximação temporal desse acervo em relação ao presente, essa conduta resultava de profícuas experiências realizadas ainda nas décadas de 1970 e 1980, a saber, a constituição do Centro Nacional de Referência Cultural - CNRC e da Fundação Nacional Pró-Memória, ambos por Aloísio Magalhães.

Assumindo a identificação do Programa Monumenta, ainda, com a tradicional política da "pedra-e-cal" do IPHAN e o critério de seleção como limite para a produção da memória e a definição de critérios objetivos de análise e trabalho, a comissão técnica partiu do estabelecimento de marcos históricos para a avaliação do acervo em vez dos de natureza artística, estes, segundo ela, sempre privilegiados pelos técnicos do IPHAN. O mote de sua atuação resumia-se a um período: "como inserir este patrimônio em uma nova narrativa da história nacional no 
qual não predomine um ponto de vista totalitário e centralizador?" (JANCSÓ, 2000, p. 6).

De forma a construir, ao mesmo tempo, um ideário e um programa de trabalho que norteasse a árdua tarefa de selecionar sítios históricos e definir o que nestes seria realizado, o grupo de técnicos estabeleceu como premissas as seguintes:

- A distinção entre o modo analítico dos historiadores e o dos arquitetos e urbanistas quanto ao patrimônio edificado. Se para estes a expressão "preservação" significa apenas o restauro arquitetônico de algum imóvel de valor, para aqueles

os imóveis devem ser preservados não por suas qualidades arquitetônicas, nem por inserirse na grande história..., mas pelo que nos revelam de outras vivências, outros modos de ser que nos precederam, que sugiram como o tempo altera e mantém os modos de vivência social no território. (JANCSÓ, 2000, p. 6);

- A consideração do bem cultural como lugar de memória, de acordo com o termo alemão Denkmal (monumento), "lugar complexo, que envolve conhecimento e sentimentos, um lugar de reconhecimento, de compartilhamento de emoções e saberes" (JANCSÓ, 2000, p. 6). Nessa perspectiva, a pertinência da preservação de um bem cultural repousaria na sua condição de emanar inteligibilidade histórica, de se constituir em produtor de memórias e de vínculos identitários, demarcando não um mas diversos níveis de memória, reforçando-se ou em franca oposição, colocando-se em cheque a associação patrimônio/memória nacional;

- A contestação do Estado e do seu papel na preservação, até então tido como protagonista único da organização da sociedade e da legitimação de sua identificação cultural, no âmbito do processo de dissociação entre patrimônio e nação:

a atribuição de valor a monumento não pode ser monopólio do Estado, mas deve contemplar a multiplicidade de significações e valores que lhe são atribuídos, em um mesmo momento e contexto, a um mesmo bem, por grupos econômico, social e culturalmente diferenciados. (JANCSÓ, 2000, p. 6); 
- No campo da valorização do patrimônio cultural, a substituição do conceito de metonímia (a parte pelo todo) pelo de sinédoque (o todo pelas partes):

\begin{abstract}
o patrimônio de caráter regional também é nacional, pois a nacionalidade não é a supressão das especificidades locais, mas as compreende. A nação não é mais entendida como unidade homogênea, mítica, original, mas como unidade que traz em si a heterogeneidade e o conflito. Há unidade na diversidade e no conflito e há conflito e heterogeneidade na unidade. (JANCSÓ, 2000, p. 7)
\end{abstract}

Essas premissas são, com efeito, determinações que guardam estreita relação com a ideologia política, econômico-financeira e administrativa estrutural do governo federal de então. A negação do papel central do Estado na preservação, na verdade, a desregulamentação desta, associada à entrada em cena das municipalidades e do setor privado, nada mais é do que uma clara referência ao primado da redução da ação da máquina estatal, mantra neoliberal entoado à exaustão no período como panacéia para a gestão (ou melhor, o gerenciamento) do país. A propósito, a visão dos arquitetos e urbanistas quanto à preservação do patrimônio edificado, tida como unicamente ligada a processos comezinhos e mecânicos de restauro, não pode ser acusada de pregar a "patrimonialização" universal nem a banalização do instituto do tombamento, pois sempre dirigida, principalmente na etapa pioneira do IPHAN, por critérios aferrados à qualidade espacial e construtiva das edificações, fossem elas produzidas por agentes eruditos ou leigos. De outra parte, a subjetividade da visão preservacionista historicista leva o assunto a terreno pantanoso, qual seja, à "museificação de tudo", a começar da cidade histórica, gerando amplas dificuldades para a administração cotidiana da preservação por muitas vezes elevar simples manifestações locais ao panteão do patrimônio nacional, ação executada muito mais pela incúria das instituições estaduais e municipais de patrimônio, omissas ou incapazes de cumprir com suas obrigações constitucionais, do que, efetivamente, pela revelação de uma unidade cultural rica, diversa, heterogênea e eivada de salutares conflitos.

Elegendo como universo mais amplo o estado-nacional brasileiro, democrático e plural, segundo as perspectivas da memória coletiva e do conhecimento, a comissão técnica privilegiou como seu critério fundador "[a] inteligibilidade maior ou menor do 
patrimônio e não [a] intensidade de emoções que possa causar" (JANCSÓ, 2000, p. 7). A classificação preliminar dos tipos de sítios e conjuntos foi estabelecida da seguinte forma:

- SHUNs, por apresentarem organicidade, complementaridade, completude, e grande densidade cronológica;

- Áreas urbanas e rurais que propiciem, como documentos relevantes, a compreensão do estado atual da ocupação do território brasileiro e da regionalização da memória nacional;

- Expressões arquitetônicas e urbanísticas que denotem antiguidade e escassez, sobretudo aquelas relacionadas aos séculos XVI e XVII;

CUMNS.

- A sistematização da tipologia dos sítios e conjuntos tomou por base o "grau de inteligibilidade, ou seja, a abrangência funcional e organicidade de seus componentes internos, na ordem de sua prioridade" (JANCSÓ, 2000, p. 8), a saber:

- SHUNs de grande, média e pequena abrangência funcional;

- CUMNs orgânico completo (conjunto inteligível, dotado de sentido unitário numa narrativa histórica, quer pela simultaneidade, complementaridade ou sequencialidade); orgânico simultâneo (elementos arquitetônicos e urbanísticos contemporâneos); orgânico complementado (elementos complementares enquanto funções urbanas); orgânico sequencial (detentor de densidade cronológica inteligível); inorgânico (configurado por elementos destituídos de complementaridade, simultaneidade e sequencialidade); e inorgânico com monumento de singular importância, este um verdadeiro ícone na História nacional.

Com essa exposição, pretendeu a comissão técnica esgotar as diversas tipologias encontradas nas cidades históricas, bem como ampliar as chances de inclusão das mesmas no programa. Vê-se claramente que não foi sua intenção privilegiar predicados tradicionalmente eleitos para distinguir sítios e conjuntos históricos (homogeneidade, legibilidade arquitetônica, unidade temporal ou de estilo), tomando inclusive situações problemáticas (heterogeneidade, descaracterização, desconformidade) como pontos de partida para novas soluções arquitetônicas e urbanísticas em que a preservação urbana atuaria como agente de requalificação e revitalização do espaço urbano. 
Por ordem de importância, foram assim elencados os critérios de priorização:

- Social (realçando o surgimento de novos atores e grupos sociais, para destaque da diversidade e pluralidade da cultura nacional);

- Regional (valorizando os chamados "vazios da memória" (JANCSÓ, 2000, p. 8): manifestações externas ao conjunto formado pelas ligadas aos estados de Minas Gerais, Rio de Janeiro, São Paulo e Bahia);

- Densidade cronológica (privilegiando a cidade histórica como um museu de expressões arquitetônicas e urbanísticas produzidas em tempos distintos, contraposto à pureza original da homogeneidade e da unidade estilística);

- Vazio cronológico (valorizando os séculos XVI, XIX e XX, pela escassa quantidade de imóveis tombados e pela importância histórica destes).

Por fim, foi construído um banco de dados digital com as seguintes informações sobre as áreas urbanas passíveis de contemplação: caracterização; localização (estado e cidade); porte da cidade; área de influência; data de fundação do sítio urbano; data de fundação do município; datação dos sítios históricos urbanos nacionais ou conjuntos urbanos de monumentos nacionais (original, predominante e final); história e descrição dos sítios históricos urbanos nacionais ou conjuntos urbanos de monumentos nacionais; e bibliografia. Com esse quadro, intentava-se elaborar uma reflexão de viés acadêmico e científico, isenta de critérios subjetivos e extremamente objetiva e pragmática quanto à eficácia do programa de preservação urbana, pretensamente protegida dos perigos verificados nas experiências de preservação urbana até então realizadas no país.

\subsection{0 processo de seleção dos SHUNs e CUMNs}

A seleção dos SHUNs e CUMNs revelou a intenção da direção do Programa Monumenta de construir uma ampla amostragem das áreas urbanas de interesse cultural existentes e assim reconhecidas no país, de maneira a contemplá-las em suas diferentes características, bem como detectando seus problemas, virtudes, potenciais e perspectivas, criando-se um ambiente de disputa entre os estados e as cidades participantes.

A listagem (ver anexos) inicialmente abrangeu 101 áreas urbanas de 22 estados (Amazonas, Alagoas, Bahia, Ceará, Espírito Santo, Goiás, Maranhão, Minas Gerais, 
Mato Grosso, Mato Grosso do Sul, Pará, Paraíba, Pernambuco, Piauí, Paraná, Rio de Janeiro, Rio Grande do Norte, Rio Grande do Sul, Santa Catarina, Sergipe, São Paulo e Tocantins) e o Distrito Federal, ficando de fora desse rol os estados do Acre, Amapá, Rondônia e Roraima. Os estados da Bahia (9 SHUNs e 11 CUMNs), Minas Gerais (12 SHUNs e 8 CUMNs) e Rio de Janeiro (8 SHUNs e 5 CUMNs) foram aqueles que tiveram classificadas mais áreas urbanas de interesse cultural pelo programa, prova da permanência, no processo seletivo, da reverência às expressões arquitetônicas e urbanísticas do século 18 e do início do século 19. Com apenas uma só menção os estados do Amazonas (conjunto arquitetônico e paisagístico do Porto de Manaus), Alagoas (conjunto histórico e paisagístico de Penedo), Espírito Santo (Cidade Alta de Vitória), Mato Grosso do Sul (conjunto histórico, arquitetônico e paisagístico de Corumbá), Paraíba (convento e igreja de Santo Antônio, em João Pessoa), Piauí (conjunto formado pela Igreja de Nossa Senhora da Vitória e o Sobrado de João Nepomuceno, em Oeiras), Rio Grande do Norte (conjunto formado pelo Palácio Potengi e pelo Museu Café Filho, em Natal) e Tocantins (conjunto arquitetônico, urbanístico e paisagístico de Natividade).

Ainda sem um ranking propriamente estabelecido, a listagem inicial do Programa Monumenta evidencia aspectos de interesse. Se as manifestações arquitetônicas e urbanísticas do barroco mineiro, da velha capital soteropolitana e da metrópole imperial ainda predominavam em número, as expressões do ecletismo (Estação da Luz - SP e o conjunto histórico e paisagístico de São Francisco do Sul - SC), o barroco sertanejo (conjunto arquitetônico e urbanístico de Icó - $\mathrm{CE}$ ), o mundo do trabalho (conjunto urbano e paisagístico da Companhia Petropolitana de Tecidos), os imigrantes (conjunto arquitetônico e urbanístico de Antônio Prado - RS), os índios (conjunto arquitetônico e urbanístico da Aldeia de Carapicuíba - SP), os negros (centro histórico de Salvador - BA) e o Modernismo (conjunto urbanístico de Brasília - DF), para citar apenas algumas mencionadas como merecedoras de valorização como patrimônio nacional, foram também contempladas.

Entretanto, fazia-se imperioso para a sequência do programa, mediante a adoção de critérios e o estabelecimento de prioridades, definir os sítios e conjuntos que seriam atendidos com os recursos financeiros do BID para a sua pronta recuperação. Para tanto, conforme previsto no contrato de empréstimo, constituiu-se um grupo de 
trabalho - GT (3), composto por especialistas independentes em patrimônio cultural; técnicos do patrimônio cultural ligados a entidades estaduais e municipais; e representantes do BID, do IPHAN, da Embratur, do Ministério da Educação e da Unesco.

Na primeira etapa dos trabalhos do GT, foram realizadas exposições preparatórias para subsidiar as decisões desta comissão, a saber, caracterização e informações gerais do programa; critérios para eleição de novas cidades; razões e objetivos de preparação da lista de prioridades; definição e critérios de identificação das áreas; banco de dados dos SHUNs e CUMNs; relação dos SHUNs e CUMNs com o processo histórico de formação da nacionalidade; construção de uma matriz de narrativa histórica e inserção de cada sítio; e descrição da tipologia de sítios e conjuntos. Como se vê, os trabalhos continuaram se dando conforme uma matriz acadêmica e científica, priorizando-se o conhecimento e a experiência prática dos integrantes de um grupo de formação necessariamente heterogênea.

Para a construção do modelo de seleção foram estabelecidos critérios de hierarquização, a saber, pluralidade; descentralização; homogeneidade/diversidade; singularidade; vazio cronológico; e risco. Esses critérios, combinados, produziram uma matriz de sítios e conjuntos (ver anexos) à qual foram atribuídos ainda pesos a cada critério. A lista inicial, contendo 101 áreas, teve seu número reduzido a 94 com a fusão de alguns sítios e conjuntos, tais como os centros históricos de Belém (conjunto do Mercado Ver-o-Peso e Praça Frei Caetano Brandão), Rio de Janeiro (Praça XV, Candelária e Cinelândia), São Luís (conjunto de São Luís e Praça Gonçalves Dias) e Salvador (Pelourinho, Pilar e Cairú), além de Sabará (Pedro II e Sabará).

A classificação final (ver anexos) exibe uma constituição equilibrada, sem concentrações regionais ou privilégios devidos à expressão arquitetônicourbanística, apesar das pressões sofridas pelo GT, de parte de políticos e comunidades, na etapa final de classificação. Começando com o conjunto arquitetônico e paisagístico de São Luís e Praça Gonçalves Dias, posição esta certamente alcançada devido à ameaça constante de degradação e destruição pairante sobre o magnífico conjunto maranhense, protegido como patrimônio cultural 
da humanidade pela Unesco, a lista mostra em seus primeiros lugares sítios e conjuntos que até então não detinham destaque nacional, como é o caso de Porto Alegre-RS, Icó-CE, Corumbá-MS e Carapicuíba-SP. As áreas urbanas de interesse cultural baianas, mineiras e cariocas, em maior número, foram posicionadas de maneira espaçada, gerando-se oportunidades de aproveitamento para sítios e conjuntos de outros estados. Assim como a sustentabilidade, a falta de vocação ou de alternativas econômicas, bem como, de outra parte, a intensa movimentação econômica devida a pujantes atividades de comércio e serviço, potenciais agentes de degradação das áreas históricas, foram aspectos considerados na eleição e classificação dos sítios e conjuntos.

Dando por encerrado o seu trabalho, o GT apresentou um conjunto de considerações e recomendações à coordenação do programa para que fossem incluídas nas ações deste, ressaltando a sua necessária continuidade e o seu permanente aperfeiçoamento: a realização de inventários de bens móveis e imóveis e de referências culturais; a valorização e preservação de acervos documentais nas áreas objeto de intervenção; a disponibilização ao público das informações sobre as áreas urbanas de interesse cultural; a reavaliação periódica da lista de prioridades face à dinâmica dos sítios e conjuntos históricos; e o aprimoramento dos critérios de análise.

\subsection{Programa Monumenta: resumo da formulação inicial}

A enumeração, análise e classificação de mais de uma centena de áreas urbanas de interesse cultural pelo Programa Monumenta expõe claramente a visão deste organismo, em sua primeira formulação, quanto à preservação urbana no Brasil. Abarcando ambiciosamente todas as regiões do país, considerando tanto capitais quanto municípios do interior, tomou conhecimento das boas e más práticas então em curso, intentando construir um marco inquestionável da preservação urbana no Brasil, numa escala até então não experimentada. Partindo de um pressuposto no mínimo polêmico (a falência da visão patrimonial do IPHAN), defendeu a valorização da diversidade e riqueza das manifestações culturais regionais, considerando a dimensão documental do patrimônio, a extensão e as imbricações de suas versões materiais e imateriais e as relações da preservação de sítios e conjuntos com a gestão urbana e o desenvolvimento sócio-econômico. Elegendo como parceiros 
preferenciais as municipalidades e o segmento privado, pugnou abertamente, em diversos fóruns, pela desregulamentação da preservação e o paulatino afastamento do Estado desta esfera de ação. Como suporte financeiro, em vez de instituições bancárias estatais brasileiras ligadas ao desenvolvimento regional ou a programas específicos de fomento e ação, o BID, com aportes ao mesmo tempo volumosos e geradores de aumento da dívida externa.

De outra parte, na condição auto-proclamada de um programa de governo situado acima das instâncias federais relacionadas ao patrimônio e à sua proteção, valorizou, numa perspectiva inclusiva, áreas urbanas, cidades e manifestações culturais até então não tidas como integrantes do patrimônio nacional, apesar de tombadas ou registradas pelo IPHAN. Inicialmente separado deste, atuando livremente e estabelecendo parcerias com órgãos pertencentes aos diversos níveis de poder, reservou para si o papel de agente formulador, organizador e fomentador da preservação urbana no país. Em vez de dar continuidade ao tradicional sistema decisório relacionado à proteção do patrimônio edificado (a autoridade do saber), tornado célebre no período dos pioneiros do IPHAN, o Monumenta fundamentou suas escolhas em critérios científicos, escandidos em modelos teórico-acadêmicos, com predominância da visão de historiadores, cientistas sociais e antropólogos, em detrimento da defendida pelos arquitetos. Sua proposta era direta: a preservação urbana é uma função a ser cumprida na/pela cidade, necessariamente integrada à gestão urbana, dotada de sustentabilidade comprovada, tributária dos processos de desenvolvimento sócio-econômico e instrumento de revitalização/requalificação de áreas urbanas de interesse cultural. Previsto inicialmente por seus formuladores para atuar sem as amarras do dirigismo político, conformou-se na sequência como um programa centrado na disputa acirrada entre as cidades constantes de sua lista, as quais, em luta por mais recursos e posições mais favoráveis no ranking, progressivamente passaram a usar artifícios, lícitos ou não, para pontuarem positivamente na grade de prioridades. Na mesma linha, as conflituosas relações que acabaram se estabelecendo com o IPHAN, por motivo da desigual partilha de responsabilidades relacionada ao cotidiano da preservação. Entretanto, novos ventos político-ideológicos logo soprariam, alterando em boa medida o arcabouço do programa. 


\section{Programa Monumenta-BID hoje: conclusões}

Como costuma acontecer no Brasil, a realidade (ou a realpolitik) transformou radicalmente o projeto inicial do Programa Monumenta. O ano de 2001 marca a ampliação territorial do programa, quando é aprovado o seu novo regulamento operativo. Mas é em 2003, com a posse do Presidente Luís Inácio Lula da Silva, que se dá a mudança primordial em sua estrutura operacional: o Monumenta, sempre insistindo na parceria com as prefeituras e os setores privados na preservação dos sítios e conjuntos sob sua gestão e autônomo em relação ao IPHAN, vê paulatinamente esse modelo se esboroar. Originalmente simpático à desregulamentação e à retração da atuação do Estado na área patrimonial, o programa se aproxima dos programas nacionais de desenvolvimento para estimular a contrapartida de estados e municípios, de maneira a aumentar sua sustentabilidade e capacidade de replicação.

O GT-IPHAN é então incorporado à UCG, que assume as funções de coordenação técnica do programa. Um termo de cooperação técnica é estabelecido entre o IPHAN e os ministérios da Cultura, das Cidades e do Meio Ambiente, visando implementar os planos diretores das cidades. Passo a passo, o Monumenta abandona o conceito da preservação guiada pelos ditames do capital e do mercado e adentra o círculo onde o patrimônio é considerado um bem estratégico, regido pela ação desenvolvimentista do Estado, associado a outras políticas setoriais afins.

Em 2004, o MinC e a Caixa Econômica Federal firmam contrato de financiamento para a recuperação de imóveis privados no âmbito do programa, operação esta realizada a juros praticamente simbólicos. Este é considerado um dos pontos altos do Monumenta, por atingir um contingente populacional carente e sempre colocado à margem das benesses da preservação. A prorrogação do Programa é autorizada pelo BID até 4 de dezembro de 2006.

Em 2005, o Programa alcança um novo patamar, ao passar a lidar com a promoção de ações de preservação sustentada. Por meio de edital, são escolhidos 77 projetos de desenvolvimento de atividades econômicas, de qualificação profissional em restauro e conservação e de criação de núcleos de educação profissional em 46 cidades históricas brasileiras. Nesse momento, as dimensões materiais e imateriais 
do patrimônio são trabalhadas conjuntamente, na perspectiva de que possam também contribuir para a garantia da sustentabilidade sócio-econômica dos locais onde o programa atua. A recuperação dos edifícios e áreas urbanas, assim como a valorização das celebrações, formas de expressão, saberes e fazeres e lugares, mediadas pela capacitação e qualificação profissionais, passam a fazer parte do cotidiano das comunidades de forma diferente, pelo fato de que, agora, além de caracterizarem a cultura de uma cidade ou região, essas expressões são também instrumentos para a melhoria do seu nível de qualidade de vida.

O ano de 2006 assinala a "virada" institucional: o Coordenador Nacional do Programa Monumenta é nomeado presidente do IPHAN e a sua estrutura administrativa incorpora-se à do instituto. Com isso, dissolve-se todo um histórico de disputas e constrangimentos entre as duas instituições, com a transformação do programa em uma efetiva ação de estado. Nessa esteira, conclui-se a seleção pública de imóveis privados, realizada nas 26 cidades do Programa, quando foram classificados 892 imóveis. Como desdobramento dessa incorporação, foram também iniciadas as discussões sobre a absorção dos métodos conceituais e gerenciais próprios do Monumenta à estrutura permanente do governo.

Com efeito, como se caracteriza, hoje, o programa e a sua atuação? Segundo as informações disponibilizadas na página do IPHAN na internet,

o Monumenta é um programa estratégico do Ministério da Cultura. Seu conceito é inovador e procura conjugar recuperação e preservação do patrimônio histórico com desenvolvimento econômico e social... Sua proposta é agir de forma integrada em cada um desses locais, promovendo obras de restauração e recuperação dos bens tombados e edificações localizadas nas áreas de projeto, além de atividades de capacitação de mão-de-obra especializada em restauro, formação de agentes locais de cultura e turismo, promoção de atividades econômicas e programas educativos. (PROGRAMA MONUMENTA, 2010).

A preocupação com a sustentabilidade financeira e sócio-econômica das ações de preservação, mantida ainda certa ressalva quanto ao emprego de fundos públicos nestas, tem a mesma escala das devotadas à manutenção das edificações e áreas urbanas e ao (re)aquecimento da economia local: 
O Monumenta..., procura garantir condições de sustentabilidade do patrimônio. Objetivo a ser alcançado com a geração de recursos para o equilíbrio financeiro das atividades desenvolvidas e que mantenham conservados os imóveis da área do projeto. Com isto, facilita a manutenção das características originais dos bens, sem que sejam necessários futuros aportes de recursos públicos. Uma das estratégias para atingir essa meta é estabelecer novos usos para os imóveis e monumentos recuperados. (PROGRAMA MONUMENTA, 2010).

As novas destinações dos imóveis restaurados geralmente se prendem a funções públicas de que os municípios se ressentem ou, mais propriamente, às atividades culturais e da indústria do turismo e do lazer. Numa palavra: é com o Monumenta (principalmente em sua segunda versão) que, efetivamente, as áreas urbanas de interesse cultural, tombadas ou não, deixam de ser consideradas unicamente pelo filtro dos conceitos de cidade-monumento e cidade-documento para se constituírem em instrumentos voltados à viabilização do desenvolvimento sócio-econômico sustentável das comunidades que as habitam:

A descoberta do patrimônio cultural como fonte de conhecimento e de rentabilidade financeira vem transformando essas áreas em pólos culturais, incentivando a economia por meio do incremento do turismo cultural e geração de empregos. O Programa conta com apoio dos estados e municípios, de forma que suas intervenções afetem, direta e indiretamente, a economia, a educação e a cultura local, e facilitem, assim, a inclusão cultural, social e econômica da população. (PROGRAMA MONUMENTA, 2010).

Uma das prerrogativas do Monumenta é estimular ações conjugadas entre governo, comunidade e iniciativa privada. Para garantir a sustentabilidade do programa, foi criado o Fundo Municipal de Preservação do Patrimônio Histórico e Cultural, cujo objetivo é

o de financiar ações de preservação e conservação das áreas submetidas à intervenção do Programa. Os recursos financeiros gerados pelas iniciativas do Monumenta em cada cidade são direcionados para o Fundo Municipal e usados para cobrir os custos de conservação do patrimônio histórico de cada município. Além disso, o Fundo pode receber recursos orçamentários do município, contrapartidas de convênios, aluguéis e arrendamentos dos imóveis e doações. (PROGRAMA MONUMENTA, 2010). 
Mesmo assim, das 101 cidades elencadas inicialmente para serem palco das atividades do programa, atualmente apenas 26 cidades o são: Alcântara-MA, BelémPA, Cachoeira-BA, Congonhas-MG, Corumbá-MS, Diamantina-MG, Goiás-GO, IcóCE, Laranjeiras-SE, Lençóis-BA, Manaus-AM, Mariana-MG, Natividade-TO, OeirasPI, Olinda-PE, Ouro Preto-MG, Pelotas-RS, Penedo-AL, Porto Alegre-RS, RecifePE, Rio de Janeiro-RJ, Salvador-BA, São Cristóvão-SE, São Francisco do Sul-SC, São Paulo-SP e Serro-MG. A disparidade entre os números das cidades propostas e das que efetivamente ofereceram condições satisfatórias para o desenvolvimento do programa evidencia as dificuldades encontradas pela instituição em estabelecer parcerias saudáveis e eficazes com as municipalidades e os setores privados. Esse, talvez, o momento em que, no cenário de promessas e realizações do programa, a realidade brasileira mostra a sua face de modo mais verdadeiro.

\section{Anexos}

QUADRO I

Listagem de Sítios Históricos Urbanos Nacionais e Conjuntos Urbanos de Monumentos Nacionais, por Estado

\begin{tabular}{|c|c|c|c|c|}
\hline $\mathbf{N}^{\circ}$ & UF & Município & S/C & Nome \\
\hline 1 & AM & Manaus & S & Conjunto Arquitetônico e Paisagístico do Porto de Manaus \\
\hline 2 & $\mathrm{AL}$ & Penedo & S & Conjunto Histórico e Paisagístico de Penedo \\
\hline 3 & BA & Cachoeira & S & Conjunto Arquitetônico e Paisagístico de Caichoeira \\
\hline 4 & BA & Itaparica & S & Conjunto Arquitetônico, Urbanistico e Paisagístico de Itaparica \\
\hline 5 & BA & Lençóis & S & Conjunto Arquitetônico e Paisagistico de Lençóis \\
\hline 6 & BA & Monte Santo & S & $\begin{array}{l}\text { Conjunto Arquitetônico, Urbanistico e Paisagístico da Serra do } \\
\text { Monte Santo }\end{array}$ \\
\hline 7 & BA & Mucugê & $\mathrm{S}$ & Conjunto Arquitetônico e Paisagístico de Mucugê \\
\hline 8 & BA & Porto Seguro & $\mathrm{S}$ & Município de Porto Seguro \\
\hline 9 & BA & $\begin{array}{l}\text { Rio de } \\
\text { Contas }\end{array}$ & $S$ & Conjunto Arquitetônico de Rio de Contas \\
\hline 10 & BA & Salvador & S & Centro Histórico de Salvador \\
\hline 11 & BA & $\begin{array}{l}\text { Santa Cruz } \\
\text { Cabrália }\end{array}$ & $S$ & $\begin{array}{l}\text { Conjunto Arquitetônico e Paisagístico da Cidade Alta de Santa Cruz } \\
\text { Cabrália }\end{array}$ \\
\hline 12 & $\mathrm{BA}$ & Jaguaripe & $\mathrm{C}$ & $\begin{array}{l}\text { Jaguaripe (Igreja Matriz Nossa Senhora Ajuda/Casa de Câmara e } \\
\text { Cadeia/Casa do Ouvidor) }\end{array}$ \\
\hline 13 & BA & Maragogipe & $\mathrm{C}$ & $\begin{array}{l}\text { Maragogipe (Igreja Matriz São Bartolomeu/Casa de Câmara e } \\
\text { Cadeia) }\end{array}$ \\
\hline
\end{tabular}




\begin{tabular}{|c|c|c|c|c|}
\hline 14 & BA & Nazaré & $\mathrm{C}$ & $\begin{array}{l}\text { Nazaré (Igreja Matriz Nossa Senhora Nazaré/Igreja Nossa Senhora } \\
\text { Conceição/Igreja Nossa Senhora Camamu) }\end{array}$ \\
\hline 15 & BA & Salvador & C & Mont Serrat (Forte Mont Serrat/Igreja e Mosteiro Mont Serrat) \\
\hline 16 & BA & Salvador & C & Penha (Igreja Nossa Senhora da Penha/Antigo Palácio Verão) \\
\hline 17 & BA & Salvador & $\mathrm{C}$ & Pilar (Igreja Pilar) \\
\hline 18 & BA & Salvador & C & Bonfim (Igreja Senhor Bonfim/Casario) \\
\hline 19 & BA & Salvador & C & $\begin{array}{l}\text { São Joaquim (Casa Pia e Colégio dos Orfãos de São Joaquim/Casa } \\
\text { à Av. Frederico Pontes) }\end{array}$ \\
\hline 20 & BA & Salvador & C & Praça Cairú (Forte São Marcelo/Alfândega à Praça Cairú) \\
\hline 21 & BA & Salvador & C & $\begin{array}{l}\text { Barra (Forte Santo Antônio da Barra/Forte Santa Maria/lgreja Santo } \\
\text { Antônio da Barra) }\end{array}$ \\
\hline 22 & BA & Santo Amaro & C & $\begin{array}{l}\text { Santo Amaro (Igreja Matriz Nossa Senhora da Purificação/Casa de } \\
\text { Câmara e Cadeia/Santa Casa }\end{array}$ \\
\hline 23 & CE & Icó & S & Conjunto Arquitetônico e Urbanistico de Icó \\
\hline 24 & CE & Sobral & $\mathrm{S}$ & Conjunto Arquitetônico e Urbanistico de Sobal \\
\hline 25 & CE & Aracati & $\mathrm{S}$ & Aracati (Casa de Câmara e Cadeia/lgreja Matriz) \\
\hline 26 & CE & Fortaleza & C & Fortaleza (Passeio Público/Teatro José de Alencar) \\
\hline 27 & DF & Brasília & $\mathrm{S}$ & Conjunto Urbanístico de Brasilia \\
\hline 28 & ES & Vitória & $\mathrm{C}$ & Cidade Alta de vitória (Igrejas/Casas) \\
\hline 29 & GO & Goiás & $\mathrm{S}$ & Conjunto Arquitetônico e Urbanistico de Goiás \\
\hline 30 & GO & $\begin{array}{l}\text { Pilar de } \\
\text { Goiás }\end{array}$ & $\mathrm{S}$ & Conjunto Arquitetônico e Paisagistico de Pilar de Goiás \\
\hline 31 & GO & Pirenópolis & $\mathrm{S}$ & Conjunto Arquitetônico, Urbanistico e Paisagístico de Pirenópolis \\
\hline 32 & MA & Alcântara & $S$ & Conjunto Arquitetônico e Urbanistico de Alcântara \\
\hline 33 & MA & São Luís & $\mathrm{S}$ & Conjunto Arquitetônico e Paisagistico de São Luís \\
\hline 34 & MA & São Luís & S & Conjunto Arquitetônico e Paisagistico da Praça São Gonçalves Dias \\
\hline 35 & MA & São Luís & C & $\begin{array}{l}\text { Fábrica Santa Amélia (antiga fábrica Santa Amélia/Fonte de } \\
\text { Pedras) }\end{array}$ \\
\hline 36 & MG & $\begin{array}{l}\text { Belo } \\
\text { Horizonte }\end{array}$ & $\mathrm{S}$ & $\begin{array}{l}\text { Conjunto Arquitetônico e Paisagistico da Orla da Lagoa da } \\
\text { Pampulha }\end{array}$ \\
\hline 37 & MG & Cataguazes & S & Conjunto Histórico, Arquitetônico e Paisagístico de Cataguazes \\
\hline 38 & MG & Congonhas & S & Conjunto Arquitetônico e Urbanístico de Congonhas do Campo \\
\hline 39 & MG & Diamantina & S & Conjunto Arquitetônico e Urbanístico de Diamantina \\
\hline 40 & MG & Mariana & S & Conjunto Arquitetônico e Urbanístico de Mariana \\
\hline 41 & MG & Nova Era & S & Conjunto Arquitetônico e Urbanístico da Praça Matriz de Nova Era \\
\hline 42 & MG & Ouro Preto & S & Conjunto Arquitetônico e Urbanístico de Ouro Preto \\
\hline
\end{tabular}




\begin{tabular}{|c|c|c|c|c|}
\hline 43 & MG & Piranga & S & $\begin{array}{l}\text { Conjunto Arq. E Paisagístico Santurário do Senhor Bom Jesus } \\
\text { Matozinhos }\end{array}$ \\
\hline 44 & MG & Sabará & S & Conjunto Arquitetônico e Urbanístico da Rua D. Pedro II \\
\hline 45 & MG & $\begin{array}{l}\text { São João del } \\
\text { Rei }\end{array}$ & S & Conjunto Arquitetônico e Urbanístico de São João Del Rei \\
\hline 46 & MG & Serro & S & Conjunto Arquitetônico e Urbanístico do Serro \\
\hline 47 & MG & Tiradentes & S & Conjunto Arquitetônico e Urbanístico de Tiradentes \\
\hline 48 & MG & Caeté & C & $\begin{array}{l}\text { Caeté (Igreja Matriz Nossa Senhora Bonsucesso/Igreja Nossa } \\
\text { Senhora Rosário/Museu Regional) }\end{array}$ \\
\hline 49 & MG & $\begin{array}{l}\text { Conceição } \\
\text { do Mato } \\
\text { Dentro }\end{array}$ & C & $\begin{array}{l}\text { Conceição do Mato Dentro (Ig. Matriz N.S. Conceição/Igreja Nossa } \\
\text { Senhora do Rosário/Chafariz) }\end{array}$ \\
\hline 50 & MG & Itavera & $\mathrm{C}$ & $\begin{array}{l}\text { Itavera (Igreja Matriz Nossa Senhora Bonsucesso/Igreja Nossa } \\
\text { Senhora do Rosário/Museu Regional) }\end{array}$ \\
\hline 51 & MG & Mariana & C & $\begin{array}{l}\text { Santa Rita Durão (Igreja Matriz Nossa Senhora Nazaré/lgreja } \\
\text { Nossa Senhora Rosário) }\end{array}$ \\
\hline 52 & MG & Minas Novas & C & $\begin{array}{l}\text { Minas Novas (Igreja Matriz São Francisco de Assis/lgreja São José } \\
\text { e São Gonçalo/Sobradão) }\end{array}$ \\
\hline 53 & MG & Sabará & C & Sabará (igrejas/passos/chafarizes) \\
\hline 54 & MG & $\begin{array}{l}\text { Santa } \\
\text { Bárbara }\end{array}$ & C & Santa Bárbara (igrejas/capelas/Centro de Cultura) \\
\hline 55 & MG & Santa Luzia & C & $\begin{array}{l}\text { Santa Luiza (Igreja Matriz Santa Luiza/Recolhimento de } \\
\text { Macaúbas/Casa Praça Matriz) }\end{array}$ \\
\hline 56 & MS & Corumbá & S & Conjunto Histórico, Arquitetônico e Paisagístico de Corumbá \\
\hline 57 & MT & Cuiabá & S & Conjunto Histórico, Arquitetônico e Paisagístico de Cuiabá \\
\hline 58 & MT & $\begin{array}{l}\text { V. Bela S. } \\
\text { Trinidade }\end{array}$ & C & $\begin{array}{l}\text { V. Bela S. Trinidade (ruínas da igreja matriz/Palácio dos Capitães } \\
\text { Generais) }\end{array}$ \\
\hline 59 & PA & Belém & S & Conjunto Arquitetônico e Paisagistico Ver-o-Peso \\
\hline 60 & PA & Belém & S & $\begin{array}{l}\text { ConJunto Arquitetônico, Urbanístico e Paisagístico da Praça Frei } \\
\text { Caetano Brandão }\end{array}$ \\
\hline 61 & PA & Belém & S & Conjunto Arquitetônico da Avenida Nazareth \\
\hline 62 & PA & Belém & S & Conjunto Arquitetônico da Avenida Governador José Malcher \\
\hline 63 & PB & João Pessoa & C & $\begin{array}{l}\text { João Pessoa (Convento e Igreja de Santo } \\
\text { Antônio/lgrejas/Sobrados) }\end{array}$ \\
\hline 64 & PE & Igarassu & S & Conjunto Arquitetônico e Paisagístico de Igarassu \\
\hline 65 & PE & Olinda & S & Conjunto Arquitetônico e Urbanístico de Olinda \\
\hline 66 & PE & Recife & S & $\begin{array}{l}\text { Conjunto Arquitetônico, Urbanístico e Paisagístico do Antigo Bairro } \\
\text { do Recife }\end{array}$ \\
\hline 67 & PE & Recife & C & Pátio de São Pedro (Igreja de São Pedro dos Clérigos/pátio) \\
\hline 68 & PE & Goiania & C & Área do Rosário (Igrejas/Convento) \\
\hline
\end{tabular}




\begin{tabular}{|c|c|c|c|c|}
\hline 69 & $\mathrm{PI}$ & Oeiras & $\mathrm{C}$ & $\begin{array}{l}\text { Oeiras (Igreja Matriz Nossa Senhora da Vitória/Sobrado João } \\
\text { Nepomuceno) }\end{array}$ \\
\hline 70 & PR & Curitiba & $\mathrm{C}$ & Curitiba (Conjunto no Entorno do Antigo Paço Municipal) \\
\hline 71 & PR & Lapa & $\mathrm{S}$ & Conjunto Arquitetônico e Paisagístico da Lapa \\
\hline 72 & PR & Paranaguá & $\mathrm{C}$ & Paranaguá (Igrejas/Colégio dos Jesuítas) \\
\hline 73 & RJ & $\begin{array}{l}\text { Angra dos } \\
\text { Reis }\end{array}$ & S & Conunto Arquitetônico e Paisagístico da localidade de Mambucada \\
\hline 74 & RJ & $\begin{array}{l}\text { Nova } \\
\text { Friburgo }\end{array}$ & S & Conunto Arquitetônico e Paisagístico da Praça Getúlio Vargas \\
\hline 75 & RJ & Parati & $\mathrm{S}$ & Conunto Arquitetônico e Paisagístico da cidade de Parati \\
\hline 76 & RJ & Petrópolis & $\mathrm{S}$ & Cojunto Urbano Paisagistico da Avenida Koeller \\
\hline 77 & RJ & Petrópolis & S & $\begin{array}{l}\text { Cojunto Urbano Paisagistico da Companhia Petropolitana de } \\
\text { Tecidos - Cascatinha }\end{array}$ \\
\hline 78 & RJ & $\begin{array}{l}\text { Rio de } \\
\text { Janeiro }\end{array}$ & S & Conjunto Arquitetônico do Morro do Valongo \\
\hline 79 & RJ & $\begin{array}{l}\text { Rio de } \\
\text { Janeiro }\end{array}$ & $\mathrm{S}$ & Área Central da Praça XV de Novembro \\
\hline 80 & RJ & Vassouras & $\mathrm{S}$ & Conjunto Urbano Paisagístico da Cidade de Vassouras \\
\hline 81 & RJ & $\begin{array}{l}\text { Angra dos } \\
\text { Reis }\end{array}$ & $\mathrm{C}$ & Centro Histório (Igrejas/Sobrados) \\
\hline 82 & RJ & Itaboraí & $\mathrm{C}$ & $\begin{array}{l}\text { Praça Central (Igreja Matriz São João Batista/Casa do Visconde de } \\
\text { Itaboraí) }\end{array}$ \\
\hline 83 & RJ & $\begin{array}{l}\text { Rio de } \\
\text { Janeiro }\end{array}$ & $\mathrm{C}$ & $\begin{array}{l}\text { Catete (Palácio do Catete com Respectivo Parque/Conjunto } \\
\text { Arquitetônico) }\end{array}$ \\
\hline 84 & RJ & $\begin{array}{l}\text { Rio de } \\
\text { Janeiro }\end{array}$ & $\mathrm{C}$ & $\begin{array}{l}\text { Cinelândia (Biblioteca Nacional/Passeio Público/Chafariz praça } \\
\text { Mahatama Gandhi) }\end{array}$ \\
\hline 85 & RJ & $\begin{array}{l}\text { Rio de } \\
\text { Janeiro }\end{array}$ & $\mathrm{C}$ & $\begin{array}{l}\text { Praça Tiradentes (Igreja do Santissimo Sacramento/Solar Visconde } \\
\text { Rio Seco/Monumento D. Pedro I) }\end{array}$ \\
\hline 86 & RN & Natal & $\mathrm{C}$ & Corredor Cultural (Palácio Potengui/Museu Café Filho) \\
\hline 87 & RS & $\begin{array}{l}\text { Antônio } \\
\text { Prado }\end{array}$ & $\mathrm{S}$ & Conjunto Arquitetônico e Urbanístico de Antônio Prado \\
\hline 88 & RS & Pelotas & $\mathrm{C}$ & Pelotas (Prédios na Praça Coronel Pedro Osório) \\
\hline 89 & RS & Pirantini & $\mathrm{C}$ & Piratini (Palácio Farroupilha/Casa de Garibaldi) \\
\hline 90 & RS & Porto Alegre & $\mathrm{S}$ & Porto Alegre (Cais do Porto/Correios e Telégrafos) \\
\hline 91 & RS & Rio Grande & $\mathrm{C}$ & Rio Grande (Igreja Matriz São Pedro/Casas da Alfândega) \\
\hline 92 & SC & Laguna & S & Conjunto Histórico de Laguna \\
\hline 93 & SC & $\begin{array}{l}\text { São } \\
\text { Francisco do } \\
\text { Sul }\end{array}$ & S & Conjunto Histórico e Paisagístico São Francisco do Sul \\
\hline
\end{tabular}

94 SC Florianópolis C Florianópolis (Casa Natal Vitor Meirelles/antiga Alfândega/Forte) 


$\begin{array}{lllll}95 & \text { SE } & \begin{array}{l}\text { São } \\ \text { Cristóvão }\end{array} & \text { S } & \text { Conjunto Arquitetônico, Urbanístico e Paisagístico de São Cristovão } \\ 96 & \text { SE } & \text { Laranjeiras } & \text { S } & \text { Conjunto Arquitetônico e Paisagístico da cidde Laranjeiras } \\ 97 & \text { SP } & \text { Carapicuíba } & \text { S } & \text { Conjunto Arquitetônico e Urbanístico da Aldeia de Carapicuíba } \\ 98 & \text { SP } & \text { Itu } & \text { C } & \begin{array}{l}\text { Itu (Convento Nossa Senhora do Carmo/lgreja Matriz Nossa } \\ \text { Senhora Candelária/Museu da República) }\end{array} \\ 99 & \text { SP } & \text { Santos } & \text { C } & \text { Santos (Casa de Câmara e Cadeia/lgrejas/Casas) } \\ 100 & \text { SP } & \text { São Paulo } & \text { C } & \text { Área da Luz (Estação Luz) } \\ 101 & \text { TO } & \text { Natividade } & \text { S } & \text { Conjunto Arquitetônico, Urbanistico e Paisagístico de Natividade }\end{array}$

\section{QUADRO II}

Lista de Prioridades de Conservação, por Ordem de Classificação

\begin{tabular}{|c|c|c|c|c|}
\hline $\mathbf{N}^{\circ}$ & UF & Município & Nome & Pontuação \\
\hline 1 & MA & São Luís & $\begin{array}{l}\text { Conjunto Arquitetônico e Paisagistico da Praça São } \\
\text { Gonçalves Dias }\end{array}$ & 0,973 \\
\hline 2 & PA & Belém & Centro Histórico (Ver-o-Peso/Praça Frei Caetano Brandão) & 0,943 \\
\hline 3 & MA & Alcântara & Conjunto Arquitetônico e Paisagistico de Alcântara & 0,903 \\
\hline 4 & GO & Goiás & Conjunto Arquitetônico e Urbanístico de Goiás & 0,893 \\
\hline 5 & PB & João Pessoa & $\begin{array}{l}\text { João Pessoa (Convento e Igreja de Santo } \\
\text { Antônio/Igrejas/Sobrados) }\end{array}$ & 0,880 \\
\hline 6 & PE & Olinda & Conjunto Arquitetônico e Urbanístico de Olinda & 0,857 \\
\hline 7 & RS & Porto Alegre & Porto Alegre (Cais do Porto/Correios e Telégrafos) & 0,844 \\
\hline 8 & BA & Cachoeira & Conjunto Arquitetônico e Paisagistico deCachoeira & 0,824 \\
\hline 9 & MG & Ouro Preto & Conjunto Arquitetônico e Urbanístico de Ouro Preto & 0,824 \\
\hline 10 & BA & Salvador & Centro Histórico (Pelourinho/Pilar/Praça Cairú) & 0,794 \\
\hline 11 & CE & Icó & Conjunto Arquitetônico e Urbanístico de Icó & 0,792 \\
\hline 12 & DF & Brasília & Conjunto Urbanístico de Brasília & 0,791 \\
\hline 13 & MS & Corumbá & Conjunto Histórico, Arquitetônico e Paisagístico de Cuiabá & 0,783 \\
\hline 14 & MG & Tiradentes & Conjunto Arquitetônico e Urbanístico de Tiradente & 0,776 \\
\hline 15 & RJ & Rio de Janeiro & $\begin{array}{l}\text { Centro Histórico (Cinelândia/Candelária/Praça XV de } \\
\text { Novembro/Praça Tiradentes) }\end{array}$ & 0,773 \\
\hline 16 & SP & Carapicuíba & $\begin{array}{l}\text { Conjunto Arquitetônico e Urbanístico de Aldeia de } \\
\text { Carapícuiba }\end{array}$ & 0,771 \\
\hline 17 & RS & Antônio Prado & $\begin{array}{l}\text { Conjunto Arquitetônico e Urbanístico de Aldeia de Antônio } \\
\text { Prado }\end{array}$ & 0,767 \\
\hline 18 & TO & Natividade & $\begin{array}{l}\text { Conjunto Arquitetônico, Urbanístico e Paisagístico de } \\
\text { Natividade }\end{array}$ & 0,766 \\
\hline 19 & MG & Congonhas & $\begin{array}{l}\text { Conjunto Arquitetônico e Urbanístico de Congonhas do } \\
\text { Campo }\end{array}$ & 0,759 \\
\hline
\end{tabular}




\begin{tabular}{|c|c|c|c|c|}
\hline 20 & MG & Diamantina & Conjunto Arquitetônico e Urbanístico de Diamantina & 0,752 \\
\hline 21 & $A L$ & Penedo & Conjunto Histórico e Paisagístico de Penedo & 0,747 \\
\hline 22 & RS & Pelotas & Pelotas (Prédios na Praça Coronel Pedro Osório) & 0,731 \\
\hline 23 & SC & $\begin{array}{l}\text { São Franciso } \\
\text { do Sul }\end{array}$ & Conjunto Histórico e Paisagístico de São Francisco do Sul & 0,731 \\
\hline 24 & $\mathrm{PI}$ & Oeiras & $\begin{array}{l}\text { Oeiras (Igreja Matriz Nossa Senhora da Vitória/Sobrado } \\
\text { João Nepomuceno) }\end{array}$ & 0,719 \\
\hline 25 & SP & São Paulo & Área da Luz (Estação da Luz) & 0,716 \\
\hline 26 & BA & Lençóis & Conjunto Histórico e Paisagístico de Lençóis & 0,709 \\
\hline 27 & SE & Laranjeiras & Conjunto Arquitetônico e Paisagistico de Laranjeiras & 0,705 \\
\hline 28 & RJ & Parati & Conjunto Arquitetônico e Paisagistico de Parati & 0,702 \\
\hline 29 & MG & Mariana & Conjunto Arquitetônico e Urbanístico de Mariana & 0,698 \\
\hline 30 & BA & Porto Seguro & Município de PortoSeguro & 0,697 \\
\hline 31 & AM & Manaus & Conjunto Arquitetônico e Paisagistico do Porto de Manaus & 0,696 \\
\hline 32 & SE & São Cristovão & $\begin{array}{l}\text { Conjunto Arquitetônico, Urbanístico e Paisagístico de São } \\
\text { Cristóvão }\end{array}$ & 0,694 \\
\hline 33 & GO & Pirenópolis & $\begin{array}{l}\text { Conjunto Arquitetônico, Urbanístico e Paisagístico de } \\
\text { Pirenópolis }\end{array}$ & 0,685 \\
\hline 34 & MG & Serro & Conjunto Arquitetônico e Urbanístico do Serro & 0,676 \\
\hline 35 & BA & Monte Santo & $\begin{array}{l}\text { Conjunto Arquitetônico, Urbanístico e Paisagístico de } \\
\text { Monte Santo }\end{array}$ & 0,672 \\
\hline 36 & $\mathrm{PE}$ & Recife & $\begin{array}{l}\text { Conjunto Arquitetônico, Urbanístico e Paisagístico do } \\
\text { Antigo Bairro do Recife }\end{array}$ & 0,652 \\
\hline 37 & ES & Vitória & Cidade Alta de Vitória (Igrejas/Casas) & 0,651 \\
\hline 38 & RJ & Petrópolis & Conjunto Urbano Paisagístico da Avenida Koeller & 0,651 \\
\hline 39 & MG & $\begin{array}{l}\text { São João Del } \\
\text { Rei }\end{array}$ & Conjunto Arquitetônico e Urbanístico de São João Del Rei & 0,646 \\
\hline 40 & SC & Laguna & Conjunto Histórico da Cidade de Laguna & 0,642 \\
\hline 41 & MT & Cuiabá & $\begin{array}{l}\text { Conjunto Arquitetônico, Urbanístico e Paisagístico de } \\
\text { Cuiabá }\end{array}$ & 0,642 \\
\hline 42 & PR & Paranaguá & Paranaguá (Igrejas/Colégio dos Jesuítas) & 0,610 \\
\hline 43 & $\mathrm{PE}$ & Goiana & Área do Rosário (Igrejas/Conventos) & 0,607 \\
\hline 44 & BA & Jaguaripe & $\begin{array}{l}\text { Jaguaripe (Igreja Matriz Nossa Senhora da Ajuda/Casa de } \\
\text { Câmara e Cadeia/Casa do Ouvidor) }\end{array}$ & 0,603 \\
\hline 45 & GO & Pilar de Góias & Conjunto Arquitetônico e Paisagistico de Pilar de Goiás & 0,603 \\
\hline 46 & RN & Natal & Corredor Cultural (Palácio Potengi/Museu Café Filho) & 0,600 \\
\hline 47 & RJ & Rio de Janeiro & Conjunto Arquitetônico e Paisagístico do Morro do Valongo & 0,596 \\
\hline 48 & CE & Aracati & Aracati (Casa de Câmara e Cadeia/lgreja Matriz) & 0,589 \\
\hline
\end{tabular}




\begin{tabular}{|c|c|c|c|c|}
\hline 49 & CE & Sobral & Conjunto Arquitetônico e Urbanístico de Sobral & 0,584 \\
\hline 50 & RS & Rio Grande & Rio Grande (Igreja Matriz São Pedro/Casas da Alfândega & 0,581 \\
\hline 51 & BA & Rio de Contas & Conjunto Arquitetônico de Rio de Contas & 0,575 \\
\hline 52 & RJ & Vassouras & Conjunto Urbano Paisagístico da Cidade de Vassouras & 0,573 \\
\hline 53 & PR & Lapa & Conjunto Arquitetônico e Paisagístico de Lapa & 0,561 \\
\hline 54 & MG & Cataguazes & $\begin{array}{l}\text { Conjunto Histórico, Arquitetônico e Paisagístico de } \\
\text { Cataguazes }\end{array}$ & 0,558 \\
\hline 55 & SC & Florianópolis & $\begin{array}{l}\text { Florianópolis (Casa Natal Vitor Meirelles/antiga } \\
\text { Alfândega/Forte) }\end{array}$ & 0,549 \\
\hline 56 & BA & $\begin{array}{l}\text { Santa Cruz de } \\
\text { Cabrália }\end{array}$ & $\begin{array}{l}\text { Conjunto Arquitetônico e Paisagístico da Cidade Alta de } \\
\text { Santa Cruz de Cabrália }\end{array}$ & 0,547 \\
\hline 57 & MG & $\begin{array}{l}\text { Conceição do } \\
\text { Mato Dentro }\end{array}$ & $\begin{array}{l}\text { Conceição do Mato Dentro (Igreja Matriz Nossa Senhora } \\
\text { Conceição/Igreja Nossa Senhora do Rosário/Chafariz) }\end{array}$ & 0,543 \\
\hline 58 & MG & Sabará & $\begin{array}{l}\text { Conjunto Arquitetônico e Urbanístico da Rua Dom Pedro } \\
\text { II/Sabará (Igrejas/passos/chafarizes) }\end{array}$ & 0,533 \\
\hline 59 & RS & Piranti & Piranti (Palácio Farroupilha/Casa de Garibaldi) & 0,529 \\
\hline 60 & MT & $\begin{array}{l}\text { Vila Bela } \\
\text { Santa } \\
\text { Trindade }\end{array}$ & $\begin{array}{l}\text { Vila Bela Santa Trindade (ruínas da Igreja Matriz/Palácio } \\
\text { dos Capitães Generais) }\end{array}$ & 0,528 \\
\hline 61 & SP & Itu & $\begin{array}{l}\text { Itu (Convento Nossa Senhora do Carmo/Igreja Matriz } \\
\text { Nossa Senhora Candelária/Museu da República) }\end{array}$ & 0,522 \\
\hline 62 & PE & Igarassu & Conjunto Arquitetônico e Paisagístico de Igarassu & 0,510 \\
\hline 63 & BA & Mucugê & Conjunto Arquitetônico e Paisagístico de Mucugê & 0,505 \\
\hline 64 & MG & Belo Horizonte & $\begin{array}{l}\text { Conjunto Arquitetônico e Paisagístico da Orla da Lagoa da } \\
\text { Pampulha }\end{array}$ & 0,504 \\
\hline 65 & PA & Belém & $\begin{array}{l}\text { Conjunto Arquitetônico da Avenida Governador José } \\
\text { Malcher }\end{array}$ & 0,498 \\
\hline 66 & PA & Belém & $\begin{array}{l}\text { Conjunto Arquitetônico da Avenida Governador José } \\
\text { Nazareth }\end{array}$ & 0,478 \\
\hline 67 & SP & Santos & Santos (Casa de Câmara e Cadeia/lgrejas/Casas) & 0,471 \\
\hline 68 & BA & Salvador & $\begin{array}{l}\text { Mont Serrat (Forte Mont Serrat/Igreja e Mosteiro Nossa } \\
\text { Senhora Mont Serrat) }\end{array}$ & 0,456 \\
\hline 69 & BA & Nazaré & $\begin{array}{l}\text { Nazazré (Igreja Matriz São Bartolomeu/Casa de Câmara e } \\
\text { Cadeia) }\end{array}$ & 0,451 \\
\hline 70 & RJ & Rio de Janeiro & $\begin{array}{l}\text { Catete (Palácio do Catete com Respectivo Parque/Conjunto } \\
\text { Arquitetônico) }\end{array}$ & 0,439 \\
\hline 71 & BA & Santo Amaro & $\begin{array}{l}\text { Santo Amaro (Igreja Matriz N. S. Purificação/Casa de } \\
\text { Câmara Cadeia/Santa Casa) }\end{array}$ & 0,431 \\
\hline 72 & RJ & Petrópolis & $\begin{array}{l}\text { Cojunto Urbano Paisagistico da Companhia Petropolitana } \\
\text { de Tecidos - Cascatinha }\end{array}$ & 0,415 \\
\hline 73 & BA & Salvador & $\begin{array}{l}\text { Barra (Forte Santo Antônio da Barra/Forte Santa } \\
\text { Maria/Igreja Santo Antônio da Barra }\end{array}$ & 0,411 \\
\hline
\end{tabular}




\begin{tabular}{|c|c|c|c|c|}
\hline 74 & BA & Salvador & $\begin{array}{l}\text { Penha (Igreja Nossa senhora da Penha/Antigo Palácio } \\
\text { Verão) }\end{array}$ & 0,411 \\
\hline 75 & MA & São Luís & $\begin{array}{l}\text { Fábrica Sana Amélia (antiga fábrica Santa Amélia/Fonte de } \\
\text { Pedras) }\end{array}$ & 0,403 \\
\hline 76 & MG & Nova Era & $\begin{array}{l}\text { Conjunto Arquitetônico e Paisagístico da Praça Matriz de } \\
\text { Nova Era }\end{array}$ & 0,403 \\
\hline 77 & MG & Santa Bárbara & Santa Bárbara (Igrejas/capelas/Centro de Cultura) & 0,402 \\
\hline 78 & BA & Salvador & Bonfim(Igreja Senhor do Bonfim/Casario) & 0,390 \\
\hline 79 & RJ & $\begin{array}{l}\text { Angra dos } \\
\text { Reis }\end{array}$ & Mambucada (Igrejas/Sobrados) & 0,388 \\
\hline 80 & MG & Santa Luzia & $\begin{array}{l}\text { Santa Luzia (Igreja Matriz Santa Luzia/Recolhimento de } \\
\text { Macaúbas/Casa Praça Matriz) }\end{array}$ & 0,386 \\
\hline 81 & BA & Maragogipe & $\begin{array}{l}\text { Maragogipe (Igreja Matriz Nossa Senhora Nazaré/lgreja } \\
\text { Nossa senhora da Conceição/lgreja Senhor } \\
\text { Bonfim/Casario) }\end{array}$ & 0,384 \\
\hline 82 & BA & Itaparica & $\begin{array}{l}\text { Conjunto Arquitetônico, Urbanístico e Paisagístico de } \\
\text { Itaparica }\end{array}$ & 0,382 \\
\hline 83 & MG & Caeté & $\begin{array}{l}\text { Caeté (Igreja Matriz Nossa Senhora Bonsucesso/lgreja N. } \\
\text { S. Rosário/Museu Regional) }\end{array}$ & 0,371 \\
\hline 84 & RJ & $\begin{array}{l}\text { Angra dos } \\
\text { Reis }\end{array}$ & $\begin{array}{l}\text { Conjunto Arquitetônico e Paisagístico da Localidade de } \\
\text { Mambucada }\end{array}$ & 0,370 \\
\hline 85 & PR & Curitiba & Curitiba - Conjunto do Entorno do Antigo Paço Municipal & 0,364 \\
\hline 86 & MG & Itaverava & $\begin{array}{l}\text { Itaverava (Igreja Matriz Santo Antônio/Sobrado Padre } \\
\text { Taborda/Casario) }\end{array}$ & 0,355 \\
\hline 87 & MG & Piranga & $\begin{array}{l}\text { Conjunto Arquitetônico e Paisagístico Santuário do Senhor } \\
\text { Bom Jesus de Matozinhos }\end{array}$ & 0,342 \\
\hline 88 & MG & Mariana & $\begin{array}{l}\text { Santa Rita Durão (Igreja Matriz Nossa Senhora do } \\
\text { Nazaré/lgreja Nossa Senhora do Rosário) }\end{array}$ & 0,342 \\
\hline 89 & MG & Minas Novas & $\begin{array}{l}\text { Minas Novas (Igreja Matriz São Francisco Assis/lgrejas São } \\
\text { José e São Gonçalo) }\end{array}$ & 0,337 \\
\hline 90 & CE & Fortaleza & Fortaleza (Passeio Público/Teatro José de Alencar) & 0,334 \\
\hline 91 & $\mathrm{PE}$ & Recife & Pátio São Pedro (Igreja de São Pedro dos Clérigos/pátio) & 0,325 \\
\hline 92 & $\mathrm{BA}$ & Salvador & $\begin{array}{l}\text { São Joaquim (Casa Pia e Colégio dos Orfãos de São } \\
\text { Joaquim/casa à Av. Fredeiro Pontes) }\end{array}$ & 0,325 \\
\hline 93 & RJ & Nova Friburgo & $\begin{array}{l}\text { Conjunto Arquitetônico e Paisagístico da praça Getúlio } \\
\text { Vargas }\end{array}$ & 0,295 \\
\hline 94 & RJ & Itaboraí & $\begin{array}{l}\text { Praça Central (Igreja Matriz São João Batista/Casa do } \\
\text { Visconde de Itaboraí) }\end{array}$ & 0,200 \\
\hline
\end{tabular}




\section{Notas}

(1) Compunham-se de formulários a serem preenchidos, a saber, Identificação; Outras Proteções Legais; Relação com o Contexto Urbano/Tipologia Funcional; Formação/Representatividade Histórico-Cultural; e Fatores de Risco Quanto à Conservação e Gestão.

(2) O grupo de trabalho era composto pelos professores Dr. István Jancsó (coordenador), Dr. Norberto Luiz Guarinello e Dr. Pedro Puntoni, do Departamento de História da USP, e pelos pesquisadores João Paulo Garrido Pimenta, Maria Luiza Ferreira de Oliveira e Fábio Joly.

(3) A comissão era formada pelos membros das seguintes categorias: Especialistas Independentes: Ângela Gutierrez, Arno Wheling, Ester Bertoletti, Golias Silva, José Fernandes Lima, Lúcio Alcântara, Luiz Carlos Villalta, Marcus Vinícius Vilaça, Padre Ernando Teixeira, Padre Pedro Inácio Schmitz, Paulo Bertran W. Chaibub; Representantes de Órgãos Internacional, Federais, Estaduais e Municipais: Alexander Nicolaeff, Briane Bicca, Carmen Inez Garcia, Iveta Avila Fernandes, Maria Adriana Castro, Maria Cecília Londres Fonseca, Paulo Chaves, Thays Pessoto.

\section{Referências bibliográficas}

BRITO, Marcelo. Gestão compartilhada do patrimônio cultural urbano. Chronica Brasil (Goiânia: Agenda 4), n. 2, p. 58-62, 2004.

CASTILHO, Ana Luísa Howard de; VARGAS, Heliana Comin (Orgs.). Intervenções em centros urbanos: objetivos, estratégias e resultados. São Paulo: Manole, 2006.

CASTRIOTA, Leonardo Barci. Patrimônio Cultural: conceitos, políticas instrumentos. São Paulo: Annablume, 2009 .

CHOAY, Françoise. A alegoria do patrimônio. São Paulo, Editora da UNESP, 2001.

CURY, Isabelle (Org.). Cartas patrimoniais. Rio de Janeiro: IPHAN, 2001.

DARLING, Arthur. Brazil's Monumenta Program: sustainable preservation of historic cities. In: MARTIN-BROWN, Joan; SERAGELDIN, Ismail; SHLUGER, Ephim (Orgs.). Historic cities and sacred sites - cultural roots for urban futures. Washington: The International Bank for Reconstruction and Development/The World Bank, 2001. p. 195201.

FONSECA, Maria Cecília Londres. O patrimônio em processo: trajetória da política federal de preservação no Brasil. Rio de Janeiro: Edições UFRJ/IPHAN, 1997.

HALÉVY, Jean Pierre. Anotações sobre o Programa Monumenta. [S.I.: s.n.], 1998. [Inédito].

JANCSÓ, Istvan (Org.). Referencial teórico para a criação de categorias de bens tombados federais a partir de seu significado histórico-cultural. São Paulo: USP, 2000. 
MARTIN-BROWN, Joan; SERAGELDIN, Ismail; SHLUGER, Ephim (Orgs.). Historic cities and sacred sites cultural roots for urban futures. Washington: The International Bank for Reconstruction and Development/The World Bank, 2001.

MENESES, Ulpiano Bezerra de. A cidade como bem cultural - Áreas envoltórias e outros dilemas, equívocos e alcance na preservação do patrimônio ambiental urbano. In: MORI, Victor Hugo (Org.). Patrimônio: atualizando o debate. São Paulo: Edições 9a SR/IPHAN, 2006. p. 36-72.

MORI, Victor Hugo. Patrimônio: atualizando o debate. São Paulo: Edições 9a SR/IPHAN, 2006.

PAC-Cidades Históricas/IPHAN. Planos de Ação para Cidades Históricas - Patrimônio Cultural e Desenvolvimento Social: Construindo o Sistema Nacional de Patrimônio Cultural. Brasília: Edições Iphan, 2009.

PROGRAMA MONUMENTA. Sítios Históricos e Conjuntos Urbanos de Monumentos Nacionais. Brasília: IPHAN/Programa Monumenta, 2005.

PROGRAMA MONUMENTA 2010. Disponível em: <http://www.monumenta.gov.br>. Acesso em: 2010.

TADDEI NETO, Pedro. Policies of historic and cultural heritage in Brazil. In: MARTIN-BROWN, Joan; SERAGELDIN, Ismail; SHLUGER, Ephim (Orgs.). Historic cities and sacred sites - cultural roots for urban futures. Washington: The International Bank for Reconstruction and Development/The World Bank, 2001. p. 4145.

WEFFORT, Francisco. Brazil: challenges of a multiethnic and multicultural society. In: MARTIN-BROWN, Joan; SERAGELDIN, Ismail; SHLUGER, Ephim (Orgs.). Historic cities and sacred sites - cultural roots for urban futures. Washington: The International Bank for Reconstruction and Development/The World Bank, 2001. p. 3540.

ZANCHETTI, Silvio; MARINHO, Geraldo; MILLET, Vera (Orgs.). Estratégias de intervenção em sítios históricos. Recife: UFPE, 1995.

\section{Créditos}

* Arquiteto e Urbanista pela Universidade Federal do Ceará (UFC), mestre e doutorando pela Faculdade de Arquitetura e Urbanismo da Universidade de São Paulo (FAUUSP); professor de Projeto Arquitetônico do Curso de Arquitetura e Urbanismo da UFC, ex-Superintendente da $4^{\text {a }}$ Superintendência Regional do Instituto do Patrimônio Histórico e Artístico Nacional (IPHAN) - Ceará, e conselheiro vitalício do Instituto de Arquitetos do Brasil (IAB).

e-mail: 3arquitetosassociados@gmail.com 